\title{
Construindo uma burocracia econômica de excelência: concursos de seleção para o Banco Nacional de Desenvolvimento Econômico e Social (BNDES), de 1955 a 2012
}

\author{
Building an economic bureaucracy of excellence: the recruitment process \\ at the Brazilian National Bank for Economic and Social Development \\ (BNDES) from 1955 to 2012
}

\author{
Elisa Klüger
}

\begin{abstract}
Resumo O artigo tem o objetivo de assinalar mudanças no perfil das elites burocráticas recrutadas para conduzir o desenvolvimento econômico brasileiro. Para tanto, faz uma descrição detalhada do processo de recrutamento dos profissionais de nível superior que integram o quadro de funcionários do Banco Nacional de Desenvolvimento Econômico e Social (BNDES). Por meio da análise dos editais dos concursos que o Banco fez de 1955 a 2012, pretende-se examinar de que modo inflexões no processo seletivo e nas características daqueles que o Banco pretende recrutar variam de acordo com a trajetória da própria instituição. Serão apresentados, portanto, eventos da história do Banco e alterações nas funções desempenhadas por ele que podem ter tido impactos sobre os procedimentos e conteúdos exigidos na seleção de pessoal. Procura-se, assim, adentrar o universo dos concursos de seleção, considerados requisitos essenciais para a produção de burocracias públicas de qualidade, a partir de uma instituição frequentemente mencionada como paradigma das ilhas de excelência da burocracia econômica do Estado brasileiro.
\end{abstract}

Palavras-chave BNDES; Concursos de Seleção; Elites Estatais.

Abstract The aim of this article is to observe changes in the profile of the bureaucratic elite recruited to lead Brazil's economic development. In order to fulfill this goal, the text presents a detailed description of the recruitment process adopted to select the staff of the Brazilian National Bank for Economic and Social Development (BNDES). By analyzing the changes in the admission process of professionals with college degree, from 1955 to 2012, we intend to inquire how the inflections in the selection procedures and in the set of characteristics and skills that the Bank looks for when

a Doutoranda do Programa de Pós-Graduação em Sociologia da Universidade de São Paulo. Bolsista de doutorado CNPQ e CAPES-PDSE. 
recruiting, vary according to the changes experienced by the institution itself. To do so, the article is going to present a set of events that occurred in history of the Bank that had impacts on the procedures and content required in the process of personnel selection. The study of the paradigmatic case of high-level bureaucracy, the one of the BNDES, allows the reader to enter the universe of selection contests, frequently considered an essential requirement for the creation and preservation of public service of excellence.

Keywords BNDES. Public Tenders. State Elites.

A pergunta que norteia este artigo é a seguinte: como são recrutadas as elites de Estado responsáveis pela gestão da economia? Duas são as formas de entrada nas principais burocracias econômicas estatais: o concurso e a indicação. A existência de concursos rigorosos e disputados para admissão de pessoal é considerada, correntemente, uma das principais características das ditas ilhas de excelência burocrática. Malgrado a atribuição, nos estudos que se ocuparam da história da formação das burocracias de excelência, de um papel decisivo à implantação dos concursos, raramente faz-se uma análise minuciosa do processo de admissão por exame. As pesquisas da área de sociologia das elites costumam focalizar os trajetos de chegada aos postos de direção das burocracias, não atendo-se à constituição do corpo regular das elites estatais. O objetivo deste texto é observar mudanças no perfil das elites burocráticas recrutadas, via concurso público, para conduzir o desenvolvimento econômico. Para tanto, descreve-se em detalhes o processo de seleção dos quadros superiores que farão carreira no Banco Nacional de Desenvolvimento Econômico e Social (BNDES). A apresentação das mudanças nos procedimentos de seleção foi combinada com apontamentos sobre a trajetória da própria instituição, já que as inflexões na centralidade e nas funções desempenhadas pelo Banco a cada momento impactam no tipo de profissional que ele necessita incorporar.

\section{INTRODUÇÃO}

Peter Evans, em seu livro Autonomia e parceria: Estados e transformação industrial (1995), caracteriza o Brasil como um caso intermediário entre um modelo "predatório" e um modelo "desenvolvimentista" de Estado. O primeiro seria regido fundamentalmente por uma lógica de lucro pessoal daqueles que ocupam as posições de poder, enquanto o segundo seria orientado primordialmente para o incentivo sistemático à transformação social e à melhora das condições cole- 
tivas. Haveria no Brasil algumas instituições e burocracias que se assemelhariam àquelas existentes nos Estados "desenvolvimentistas": com funcionários altamente especializados, carreiras prestigiosas, bem conectadas aos setores estratégicos da sociedade e que, na área econômica, atuariam no sentido de viabilizar investimentos produtivos de longo prazo, fornecendo capital e direcionando racionalmente a alocação dos recursos (Evans, 1995, p. 44-48). Essas instituições, caracterizadas como ilhas ou bolsões de excelência/eficiência, teriam sido criadas com o intuito de escapar à lógica clientelista que prevaleceria na burocracia tradicional e nas arenas políticas brasileiras, e seriam espaços nos quais os técnicos teriam autonomia relativa para planejar, financiar e implementar projetos racionalmente. A Superintendência da Moeda e do Crédito, a Petrobrás, os Grupos Executivos de Juscelino Kubitschek, a Assessoria Econômica Vargas e o BNDE podem ser listados entre os primeiros organismos com essas características, tendo tido importante papel no desenvolvimento brasileiro a partir de meados do século XX (GEDDES, 1990, p. 225; GouvÊA, 1994, p. 117; Evans, 1995, p. 61; NunES, 1984, p. 137-138; SchneIDER, 1991; MARTINS, 1985).

O BNDE(S) poderia ser caracterizado como uma burocracia exemplar no que concerne à sua política de recrutamento e gerenciamento de quadros: os funcionários do Banco são recrutados por concurso desde os anos 1950, e os diretores convidados por indicação são, via de regra, especialistas em Economia com uma produção acadêmica reconhecida e/ou com uma atuação de destaque em órgãos econômicos públicos e grupos privados. Eles são escolhidos de acordo com o conhecimento e a legitimidade que têm para desempenhar a função de conduzir a economia nacional, pela afinidade que têm com o projeto político desenvolvido pelo governo, bem como pela amplitude de suas conexões com os setores financeiro e produtivo, essenciais para aproximar o Banco dos agentes econômicos. É possível dizer que, nos últimos 20 anos, os diretores indicados são, em sua maioria, portadores de certificações de competências teóricas e técnicas ainda mais prestigiosas do que aquelas detidas pelos funcionários concursados. Por exemplo, 48,3\% dos diretores convidados que o BNDES teve de 1994 a 2011 completaram doutorado, em contraste com $17,6 \%$ dos diretores de carreira.

Os estudos de Loureiro e Abrucio (1998) e Olivieri (2007; 2011) sobre a relação entre burocracia e política propõem-se a analisar os padrões de preenchimento dos cargos do alto escalão ministerial e do Banco Central, com a intenção de avaliar quais lógicas presidem a escolha daqueles que têm o poder de dirigir as ditas ilhas de excelência. Este artigo adentrará outra das ditas ilhas de excelência da burocracia brasileira, o BNDES, e alterará o grupo estudado: em vez de observar 
o processo de nomeação para os cargos de confiança, o alvo da análise recai sobre os concursos públicos de seleção dos quadros de nível superior, entendidos como o fundamento primário da excelência burocrática. Considerando que parte dessas instituições combina, no topo da hierarquia, dirigentes que ingressaram na instituição somente para ocupar cargos de confiança e diretores oriundos da própria burocracia que chegam ao topo da organização, o estudo do recrutamento inicial para a burocracia torna-se relevante inclusive para compreender a composição das equipes de direção, já que se ocupa do acesso à instituição de profissionais que poderão vir a integrar futuras diretorias ${ }^{1}$.

Uma vantagem adicional da análise dos concursos é que eles oferecem pistas para interpretar as inflexões vividas pela instituição analisada, isto porque o perfil dos profissionais com formação de nível superior por ela contratados varia em função das necessidades e prioridades da burocracia em um determinado ponto do tempo. Assim, cada coorte de funcionários contratados pela instituição tem características distintas, que variam em consonância com o formato e o conteúdo do exame adotado naquele ano. Inclusive a presença ou ausência de concursos em um determinado período é elemento relevante para o estudo da burocracia, uma vez que pode sinalizar aumento ou redução do prestígio e da centralidade da instituição no conjunto dos organismos de Estado. É preciso, pois, conjugar o estudo dos concursos com a apresentação das principais funções e tarefas desempenhadas pela burocracia estudada e com a decodificação de sua posição no conjunto dos órgãos do Estado a cada momento.

As etapas percorridas para descrever e analisar as transmutações experimentadas pelos processos de admissão por concurso para o BNDE(S) serão: 1) Apresentação do quadro de admissões por concurso público de advogados, contadores, economistas e engenheiros. 2) Exposição das inflexões centrais nos editais de seleção para as carreiras de engenheiro e economista, explorando as mudanças nos procedimentos de seleção e no conteúdo contemplado no exame. 3) A apresentação dos procedimentos de exame nos anos que correspondem aos governos Fernando Henrique Cardoso e Luiz Inácio Lula da Silva, será complementada por uma discussão acerca das áreas de concentração da bibliografia recomendada aos engenheiros e economistas. A escolha dessas duas carreiras deve-se a sua centralidade e prestígio no Banco. É evidência disso, por exemplo, o dado segundo o qual metade dos diretores do período 1994-2011 que ingressaram por concurso no

1 Um artigo que tematiza a composição da diretoria do BNDES e analisa os canais de acesso aos postos de confiança do Banco está em elaboração. 
Banco eram graduados em engenharia e um terço em economia. Além disso, quase todos os engenheiros que foram diretores tinham diploma da área de engenharia de produção ou formação complementar em economia/administração, sendo, pois, híbridos de engenheiro e economista.

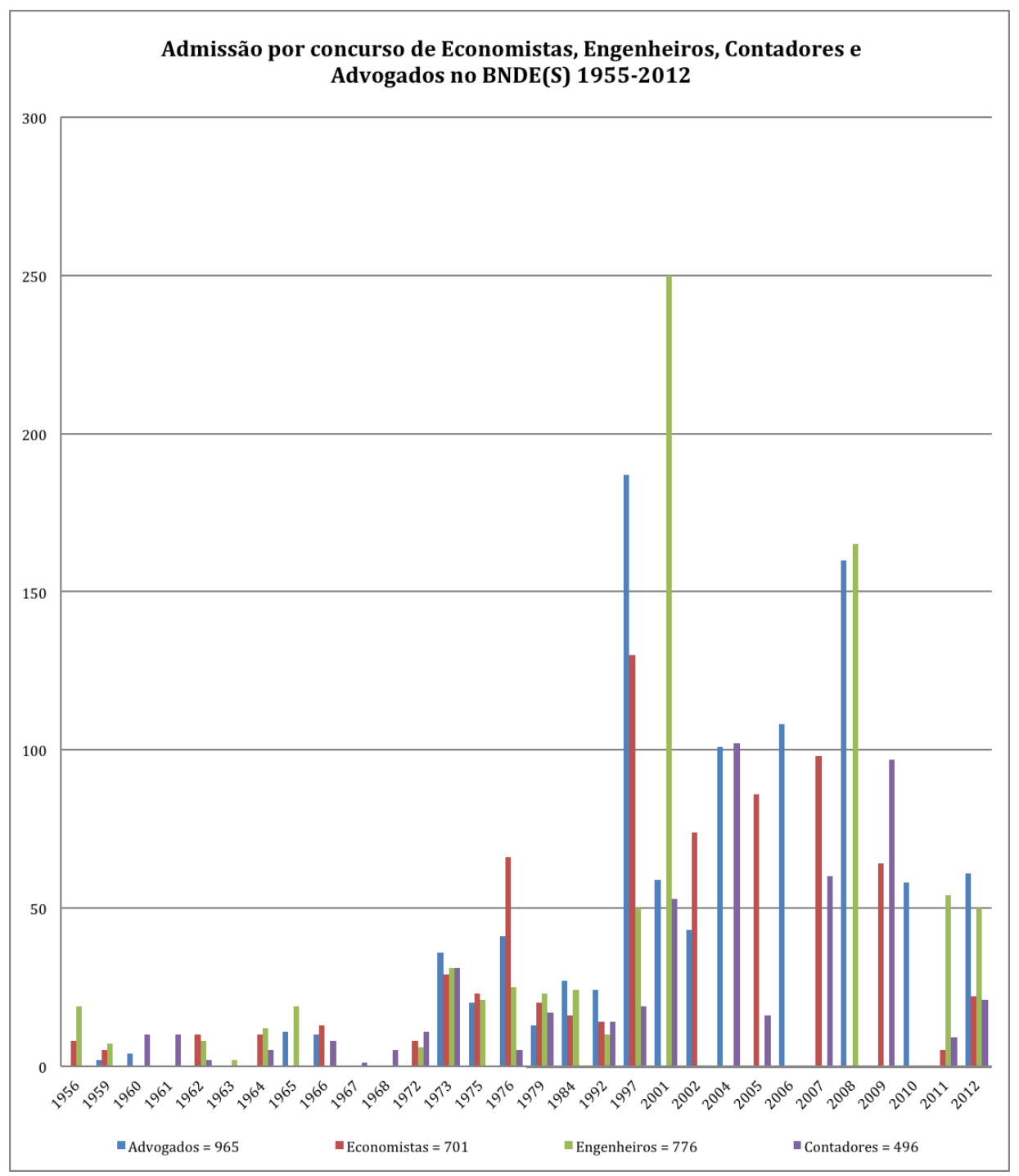

Gráfico 1. Admissão por concurso de Economistas, Engenheiros, Contadores e Advogados no BNDE(S) 1955-2012. Fonte: editais de seleção e listas de admissão para o BNDE(S) de 1955 a 2012 fornecidos pelo Serviço de Informação ao Cidadão do BNDES. Elaboração: própria².

2 Notas sobre a construção do gráfico: 1) Em alguns anos só há informações sobre o número de vagas abertas e sobre os candidatos habilitados, não sendo possível dizer, portanto, se os candidatos habilitados foram convocados em momentos posteriores, já que alguns concursos são válidos por mais de um ano. Em outros casos consta a data na qual a pessoa ingressou efetivamente no Banco ou há anotações que indicam que o candidato foi convocado em momento posterior, solucionando esse problema. 2) A contagem do número de admissões não inclui aqueles que entraram no Banco através dos prêmios BNDES, os profissionais requisitados de 


\section{PENSADORES DO DESENVOLVIMENTO BRASILEIRO E ANALISTAS DE PROJETOS (1955-1962)}

Lembro perfeitamente que, diante dos primeiros pedidos de financiamento ao BNDES, ficávamos perplexos. Como dar andamento àquilo? Como fazer? Ninguém sabia - e não sabia nem a parte burocrática, nem a legal, nem a técnica. Foi quando se começou a estruturar um setor legal, um setor técnico, e assim por diante. Da parte técnica, aliás, ninguém entendia nada, porque éramos todos economistas (Juvenal Osório, economista do BNDE, in: BNDES, 2002, p. 44).

Criado em 20 de junho de 1952, o Banco Nacional de Desenvolvimento Econômico (BNDE) começou sua vida institucional funcionando em algumas salas do edifício do Ministério da Fazenda, no Rio de Janeiro. Naquele momento o Banco contava com os diretores indicados e alguns poucos funcionários, auxiliados pelos servidores que atendiam a Comissão Mista Brasil-Estados Unidos ${ }^{3}$ e por prestadores de serviço autônomos. Um ano após o início das atividades, o Banco passou a contar com um grupo de funcionários próprio, composto por 6 advogados, 10 economistas, 12 engenheiros, 31 assistentes técnicos e 91 auxiliares administrativos, admitidos sem a realização de um concurso público (BNDES, 2002, p. 31). O primeiro edital de concurso de admissão para o BNDE foi lançado em 1955, pelo superintendente do Banco, Roberto Campos, e homologado em 1956. Além de um conjunto de assistentes e técnicos, foram contratados 8 economistas e 19 engenheiros.

O processo de seleção de economistas no exame de 1955-1956 consistia em um exame escrito de conhecimentos específicos de economia e uma prova de monografia, na qual o candidato deveria apresentar, até 90 dias depois do encerramento das inscrições, uma dissertação inédita e original, que seria avaliada por escrito e arguida oralmente. Tal dissertação deveria versar sobre um dos seguintes tópicos:

outros órgãos governamentais, aqueles que entraram através das subsidiárias do Banco ou por qualquer outro canal que não a admissão por concurso nos anos assinalados. Desse modo, os números apresentados estão longe de ser um retrato do número total de profissionais dessas carreiras que passaram pelo Banco. 3) No ano de 1976 a seleção foi dividida por área de atuação e não por título universitário. Há, pois, uma dificuldade para diferenciar os economistas dos engenheiros (ver adiante).

3 A Comissão Mista Brasil-Estados Unidos (CMBEU), composta por técnicos brasileiros e norte-americanos, tinha a missão de elaborar relatórios sobre as condições econômicas brasileiras e de formular projetos essenciais para eliminar os obstáculos ao desenvolvimento econômico. A Comissão deixa, além dos projetos de desenvolvimento por ela selecionados, ao menos dois legados fundamentais ao Brasil: a expertise para formulação e análise de projetos e o BNDE, instituição criada para administrar os financiamentos que o Brasil e os Estados Unidos fariam aos 41 projetos por ela aprovados (CMBeu, 2008, p. 285; SolA, 1998, p. 95; D’AraÚJo, 1992, p. 162). 
1) Teorias sobre o desenvolvimento econômico; formação de capital. 2) Teorias sobre poupança, investimento e relação capital-produto. 3) Métodos de financiamento do desenvolvimento econômico. Fontes de poupança pública e privada e métodos para incrementá-la. 4) Política fiscal e desenvolvimento econômico. 5) Desenvolvimento econômico espontâneo e programado; métodos de influenciar o ritmo e direção do desenvolvimento. 6) Técnicas de elaboração de projetos de investimento. 7) Desenvolvimento industrial e desenvolvimento agrícola. 8) Problemas de Industrialização. 9) Inflação e desenvolvimento econômico. 10) Produtividade. 11) Critérios para seleção de investimentos prioritários. 12) Investimentos estrangeiros. 13) Balanço de pagamentos. 14) Intercâmbio comercial e relações de troca. 15) Cooperação econômica internacional. 16) Política anticíclica. 17) Coordenação da política econômica e fiscal em sistemas federais de governo. 18) Economia dos transportes e da energia. 19) Economias regionais. 20) Estruturas do mercado e progresso econômico.

Já no caso dos engenheiros, havia um exame escrito que avaliava se o candidato dispunha dos conhecimentos técnicos requeridos para fazer análise econômica e financeira de investimentos e se possuía domínio dos temas "princípios de organização racional do trabalho" e "técnica e prática de organização industrial”. A etapa seguinte consistia em uma avaliação prática que exigia a elaboração de um roteiro de análise e de um relatório técnico avaliando um projeto de financiamento na área de transportes, energia ou indústria. Em 1959, o exame não sofreu alterações. Já o edital de 1961 manteve o exame prático para os engenheiros, mas alterou o conteúdo da prova escrita, que passou a incluir tópicos semelhantes aos da seleção de economistas, como "matemática financeira, estatística, juros, tarifas e preços”, anunciando a tendência que se acentuaria nos próximos anos.

Os editais da primeira década de funcionamento do Banco estavam direcionados à seleção de economistas especializados nas áreas de desenvolvimento e planejamento, e engenheiros que fossem capazes de avaliar projetos de investimento seguindo critérios de viabilidade técnica e econômica. Nesses anos iniciais, os únicos conhecimentos setoriais específicos exigidos diziam respeito às áreas de transportes e energia, que respondiam por 69,1\% do capital investido entre 1952 e 1963 (LimA, 2006, p. 52, 58 e 67).

No governo Juscelino Kubitschek, o presidente do BNDE chefiava o Conselho de Desenvolvimento, órgão centralizador das decisões do Plano de Metas. A relação entre o Conselho e o Banco transbordava o nível da coincidência de chefia, já que 
o primeiro reunia-se em um andar do mesmo edifício no qual estava localizado o BNDE:

[...] as secretárias eram requisitadas ao BNDE para fazer serviços de datilografia ou de pesquisa, o conselho pedia ao BNDE que contratasse estatísticos para fazer levantamentos, e assim por diante. O BNDE naquela época ainda estava numa fase inicial, não tinha muito dinheiro para aplicar, não tinha muitos projetos a fazer, de modo que houve uma fusão interessante (LoPEs, 1991, p. 172).

Havia uma convergência entre o papel de desenhista de rotas para o desenvolvimento brasileiro desempenhado pelo BNDE e pelo Conselho de Desenvolvimento ao longo desses anos e o modelo de seleção adotado. A exigência de uma monografia em formato similar à requerida para obtenção de um título acadêmico sugere que, à época, desejava-se atrair profissionais que dominassem teoria e fossem capazes de analisar a situação econômica, fazer projeções amplas sobre os rumos do desenvolvimento brasileiro e elaborar um planejamento geral para o país. Não é fortuito, pois, que figurassem entre os dirigentes do Banco nesse momento Roberto Campos e Celso Furtado, e que, por esse método de seleção, tenha ingressado no BNDE Ignácio Rangel. Nesse sentido, entende-se a afirmação de Juvenal Osório que sugere que eram todos economistas teóricos e, portanto, pouco sabiam sobre operacionalização bancária. Complementarmente, buscava-se recrutar engenheiros capazes de avaliar projetos de financiamento, sobretudo nas áreas de transportes e energia, priorizadas pela instituição nesse período, em que foram concursados, no total, 8 advogados, 22 contadores, 23 economistas e 34 engenheiros, totalizando 87 profissionais nessas 4 carreiras.

\section{ESPECIALIZAÇÃO E PROPULSÃO DA INDÚSTRIA (1963-1966)}

É importante assinalar que o Banco, nessa época, tinha perdido certo vínculo com o passado, quando havia feito estudos importantes na área econômica como herdeiro dos projetos da Comissão Mista Brasil-Estados Unidos e do Grupo Misto Cepal-BNDE, que fez um planejamento a longo prazo para a economia brasileira. Essa herança fantástica deveria retornar, e teríamos que implementar estudos de igual qualidade. No Departamento Econômico, iniciamos vários estudos de muito boa qualidade na área de fertilizantes, metais não-ferrosos, siderurgia, indústria química etc. (José Clemente, economista do BNDE, in: BNDES, 2002, p. 70). 
O edital lançado em 1963, que contratou economistas para o ano de 1964, abandonou a prova de monografia e passou a adotar, para os economistas, um modelo de exame semelhante ao que era utilizado para selecionar engenheiros: uma prova prática com o tema "desenvolvimento econômico", na qual o candidato deveria apresentar suas respostas na forma de pareceres com "apreciação, análise, conclusões recomendadas e justificativas das mesmas”. Além da prova, o candidato seria submetido a um exame teórico de conhecimentos econômicos e a uma prova de estatística. No ano de 1965, diversificaram-se os temas da prova aplicada, podendo o candidato optar entre: "a renda nacional: conceitos metodológicos e teóricos", "o sistema de preços", "desenvolvimento econômico" ou "técnica de elaboração e análise de projetos de investimento". Tal diversificação reduziu o peso dos conhecimentos sobre "desenvolvimento econômico" na seleção. A substituição do exame de feições acadêmicas por um exame presencial, com tempo delimitado e questões previamente definidas, a inclusão de temas de economia aplicada no exame prático e a adoção de exames de estatística e cálculo são evidências de que a nova gestão buscava admitir profissionais com maior domínio técnico, em vez de economistas teóricos com pouco treinamento operacional.

A transição no papel desempenhado pelo BNDE no cenário nacional no início do governo militar teve afinidade com as transformações assinaladas. Se o Banco foi central na formulação da política de desenvolvimento durante o Plano de Metas, os governos seguintes não lhe deram semelhante espaço na concepção das estratégias nacionais. Nos governos Jânio Quadros e João Goulart, o BNDE foi dirigido por figuras sem grande prestígio técnico ou proeminência intelectual: José Vicente de Faria Lima, um quadro da aeronáutica que viria a ser eleito prefeito de São Paulo, e Leocádio Antunes, um gaúcho que fora deputado estadual pelo PTB e secretário de finanças de Leonel Brizola 4 . O esvaziamento do BNDE era tamanho que, entre junho de 1963 e abril de 1964, o superintendente exerceu interinamente a presidência, pois não se logrou a nomeação de novo titular.

A designação de Roberto Campos, que havia sido fundador, superintendente e presidente do BNDE, para o Ministério do Planejamento em 1964, não fez com que o Banco reconquistasse a definição da política de desenvolvimento. Campos tivera uma série de aborrecimentos no final de seu período como presidente do Banco. Saiu de lá conhecido como "Bob Fields", o entreguista, e arrastou com ele vários altos quadros da instituição. Restaram ali os funcionários que ele concursara e que,

4 Ver Dicionário Histórico Biográfico Brasileiro (DHBB) eletrônico: verbetes Leocádio Antunes e Vicente Faria Lima. Disponível em http://cpdoc.fgv.br/acervo/dhbb. 
para seu desgosto, identificavam-se majoritariamente com os segmentos nacionalistas com os quais atritara no final dos anos $1950^{5}$ (CAMPos, 1994, p. 349-369). O Ministro Campos decidiu afastar o BNDE do núcleo de planejamento e criar uma nova instituição destinada ao estudo e à concepção das políticas econômicas e de desenvolvimento: o Escritório de Pesquisa Econômica Aplicada (EPEA). Ligado ao governo, porém independente de sua rotina administrativa, o EPEA não recrutava seus funcionários por concurso, o que permitia aos dirigentes escolher cuidadosamente os seus quadros (João Paulo dos Reis Velloso, in: D’AraúJo et al., 2005, p. 21-23). Na direção do BNDE não foi colocado um desenvolvimentista proeminente, e sim um monetarista do grupo do Ministro da Fazenda, Octávio Bulhões, que estava mais preocupado com a estabilização das finanças públicas e com o combate à inflação do que com o financiamento do desenvolvimento. Assim, O BNDE passou de planejador econômico a agente executor de políticas desenhadas por outros organismos governamentais, notavelmente o EPEA.

A substituição do exame de cunho acadêmico pela análise de um projeto de investimento e a adoção de uma prova de estatística separada do exame teórico de economia são indícios de que o processo seletivo passou a mirar o recrutamento de economistas com habilidades práticas, em lugar de teóricos do desenvolvimento econômico. Esse movimento condiz com a transição na função do Banco, já que seus funcionários passariam a ser, primordialmente, operadores de políticas delineadas alhures.

No caso dos engenheiros, a prova prática sofre uma alteração que ilustra a abertura do BNDE para novas áreas de investimento, como mencionado no depoimento de José Clemente. Se, até então, energia e transportes figuravam como incontestáveis prioridades, a partir de meados dos anos 1960 a indústria passa ao centro das preocupações do Banco. A criação da Rede Ferroviária Federal (1957), da Eletrobrás (1962) e da Embratel (1965) colaborou para que o Banco pudesse reduzir a parcela de investimentos em infraestrutura e conseguisse injetar capital em outros setores. Nesse período a siderurgia passou a concentrar mais da metade dos investimentos do BNDE, rendendo-lhe o apelido de Banco do Aço. Também as áreas de papel e celulose, petroquímica, fiação e tecidos, borracha e refrigeração passaram a ter papel de destaque no rol dos financiamentos do Banco (TAVARES,

5 Esse atrito não marcou a instituição desde o início de suas atividade, já que nos anos 1950 predominava uma oposição entre aqueles que tinham formação técnica e aqueles que ingressavam no Banco apenas por indicação dos políticos, sem ter reconhecidas competências especializadas na área econômica (KLÜGER, 2014). 
2010, p. 127-128) ${ }^{6}$. Em sintonia com as novas prioridades, a partir de 1963, além dos segmentos de transportes e energia e indústria em geral, o candidato podia optar, no exame prático, pelos setores de: agroindústrias e armazenagem, mineração e metal, elétrica e mecânica ou química e petroquímica. Nesse período o Banco incorporou mais 13 contadores, 21 advogados, 23 economistas e 33 engenheiros, totalizando 90 profissionais de nível superior nessas 4 carreiras.

\section{DA CRISE DO FINAL DOS ANOS 1960 AO BNDE GRANDE, SETORIAL E FINANCEIRO DE 1970}

Meu antecessor, Jayme Magrassi de Sá, era uma pessoa muito correta e decente, mas um unha de fome. [...] Não é brincadeira não. Não fez, na presidência, nenhum concurso público para renovar os quadros. [...]. O Banco estava estagnado, empobrecido e envelhecido. Admitir alguém, nem pensar! Fiz então uma coisa que pouca gente sabe exatamente como aconteceu. [...] propus contratar a [consultoria] Booz-Allen Hamilton para fazer uma análise e um projeto de reforma administrativa. Todo mundo topou (Marcos Vianna, presidente do BNDE, in: TAVAREs, 2010, p. 295).

Em 1967 Antonio Delfim Netto tornou-se Ministro da Fazenda. Ele ficou conhecido como o Czar da economia brasileira, por sua capacidade de espalhar leais colaboradores nos diversos órgãos encarregados da elaboração e condução da política econômica, mantendo, por extensão, o controle dos meandros do Estado (SCHNEIDER, 1991, p. 91). Uma questão a ser colocada é: se Delfim conseguiu criar uma extensa rede de colaboradores espalhados pela administração econômica do Estado, tendo sido capaz de instalar aliados no Banco Central, no IPEA7 e nas empresas estatais, por que nenhum de seus colaboradores mais próximos foi enviado ao BNDE?

Durante o governo Costa e Silva o presidente do Banco foi o contador e economista Jayme Magrassi de Sá, que ingressara no BNDE por concurso e que havia

6 A diversificação da atuação do Banco resultava também da criação dos fundos especiais como o FINAME, voltado ao financiamento da compra e venda de máquinas e equipamentos, o FUNTEC, dirigido ao estímulo e financiamento à formação de pesquisadores e ao reequipamento dos centros de pesquisa, e o FIPEME, para pequenas e médias empresas. Ver Tavares (2010, capítulo 4).

7 Em fevereiro de 1967, o EPEA muda seu nome para Instituto de Pesquisa Econômico-Social Aplicada (IPEA), nome que é alterado novamente em janeiro de 1969, passando a ser: Instituto de Planejamento Econômico e Social (IPEA). O nome é alterado uma vez mais, em maio de 1990, quando o órgão passa a chamar-se Instituto de Pesquisa Econômica Aplicada (IPEA). 
frequentado a Escola Superior de Guerra, aproximando-se dos militares ${ }^{8}$. Ele não tinha prestígio nacional nem os ouvidos do poderoso Ministro da Fazenda, ficando totalmente à margem das decisões econômicas. Magrassi permaneceu no Banco até 1970, quando caiu por ter feito declarações públicas nas quais dizia que a política econômica de Delfim Netto era irracional, inflacionária e concentradora de renda ${ }^{9}$.

O presidente seguinte, Marcos Vianna, que fora designado para o BNDE pelo Ministro do Planejamento, João Paulo dos Reis Velloso, menciona, no trecho citado acima, que Magrassi não fizera nenhum concurso para o Banco, provocando desatualização e envelhecimento do corpo funcional ${ }^{10}$. Isso em um cenário nacional que não era de estagnação - ao contrário, o país estava crescendo em média 8,5\% ao ano e o orçamento do Banco havia praticamente dobrado de 1967 a 1970 (PROchNik, 1995, p. 162-163; LIMA, 2006, p. 72). A ausência de concursos deve ser lida não como uma idiossincrasia de um presidente "unha de fome", mas como uma evidência da perda de prestígio que a instituição vinha sofrendo por quase uma década. Afinal, caso ela fosse um instrumento central do planejamento, não se deixaria que ela fosse esvaziada, não importando quão sovina fosse seu presidente.

A parceria Velloso-Vianna acabou com o isolamento do Banco e restaurou seu prestígio. Nos nove anos de presidência de Marcos Vianna, engenheiro formado pela Universidade do Brasil que havia sido diretor da Vale do Rio Doce por mais de dez anos, ocorreram mudanças essenciais tanto na estrutura do Banco quanto no processo de recrutamento. Tentando modernizar a instituição, Marcos Vianna decidiu promover uma reorganização administrativa com a ajuda de uma consultoria externa, a Booz-Allen Hamilton. A pergunta que a consultoria propunha era: quais deveriam ser as novas funções do BNDE em um país que, à época, parecia estar atrelado à locomotiva do crescimento?

Uma das modificações centrais introduzidas pela reforma promovida por Marcos Vianna foi a separação do setor de planejamento e prioridades da área de orçamento e concessão de crédito. O BNDE passou a ter uma veia operacional, que analisava a viabilidade e bancabilidade dos projetos, e uma divisão dedicada à reflexão sobre o desenvolvimento e à definição de prioridades de longo prazo. Assim, procurava-se restaurar o papel de agência de desenvolvimento capaz de conceber um planejamento econômico que atravessasse gestões governamentais. Ademais, o Banco passou do regime de autarquia governamental ao de empresa

8 Ver DHBB eletrônico: verbete Jayme Magrassi de Sá. Disponível em http://cpdoc.fgv.br/acervo/ dhbb.

9 Ver: Correio da Manhã, Ano I, número 24, Rio de Janeiro, 5 de setembro de 1970.

10 Na realidade, Magrassi repôs por concurso 27 contadores. 
pública, o que deu à instituição maior flexibilidade para estabelecer contratos, usar seus recursos e contratar pessoal, além de permitir que empresas subsidiárias se ligassem ao Banco. O fundo de financiamento para aquisição de máquinas e equipamentos (FINAME) foi convertido em subsidiária em 1971. Em 1974 surgiram três outras empresas ligadas ao Banco: a Mecânica Brasileira S.A. (EMBRAMEC), a Insumos Básicos S.A. (FIBASE) e a Investimentos Brasileiros S.A. (IBRASA), reunidas em 1982 para formar a BNDES Participações (BNDESPAR) (CABRIA, 2012, p. 192; VIANNA, 2009, p. 77-78).

Em 1974, Marcos Vianna negociou com Ernesto Geisel a atribuição ao BNDE de uma nova e estável fonte de recursos, proveniente dos fundos do Programa de Integração Social (PIS) e do Programa de Formação do Patrimônio do Servidor Público (PASEP). O adicional do Imposto de Renda, que foi a primeira fonte de financiamento do Banco, tinha sido estabelecido inicialmente por 5 anos, de 1952 a 1957. Durante o Plano de Metas, a diretoria do Banco conseguiu renovar o acordo por mais dez anos. Findos esses dez anos, o Banco contava apenas com os retornos dos investimentos que fizera até então e com repasses do orçamento, que dependiam de negociações diretas com o Conselho Monetário. Ainda que o Banco não tivesse visto sua receita diminuir no período, ele dependia ano a ano da boa vontade dos governantes. A conquista de uma fonte de renda fixa aumentava a autonomia relativa do BNDE e permitia que os planos traçados pelo Departamento de Prioridades fossem executados com regularidade. No primeiro ano em que o Banco recebeu os recursos do PIS/PASEP o orçamento subiu de $753.181 \mathrm{mil}$ dólares, em 1973, para 1.609.720 mil dólares, em 1974, e chegou no final da gestão Vianna a 4.998.145 mil dólares (Prochnik, 1995, p. 163-164).

Com nova estrutura jurídica, administrativa e de recursos, o BNDE passaria a ter, no governo Geisel, uma centralidade que não tinha desde o fim do governo JK. Em 1974, Delfim Netto deixou o Ministério da Fazenda, o que permitiu que o Ministro do Planejamento, João Paulo dos Reis Velloso, passasse a ter maior poder sobre a definição da política econômica do governo. Velloso e Vianna tiveram uma atuação integrada na implementação do Segundo Plano Nacional de Desenvolvimento (II PND), que recolocou o BNDE em uma posição central. O II PND teve início em um cenário de desequilíbrio do balanço de pagamentos, causado pela primeira crise do petróleo. Em vez de promover um ajuste recessivo, o governo Geisel elevou o grau de investimento, financiando o crescimento industrial e as obras de infraestrutura com expansão monetária e endividamento externo, o que concorreu para levar o país ao descontrole inflacionário do início dos anos 1980. O Plano de Geisel procurava contornar a crise propulsando uma nova onda de 
substituição de importações, com o objetivo de reduzir a dependência externa do país. Aceleraram-se os investimentos nas áreas de prospecção de petróleo e produção de energia hidrelétrica, bem como os incentivos e financiamentos à implantação de indústrias de transformação, de bens de capital e eletrônica, que, uma vez implementadas, deveriam ajudar o país a acumular divisas, reduzindo sua dependência externa (CARNEIRO, 1990).

Como as alterações nos concursos vinculam-se a essas mudanças? O primeiro dado a ser destacado é a amplitude que os concursos ganharam sob a presidência de Marcos Vianna, com a admissão de 100 contadores, 106 engenheiros, 110 advogados e 146 economistas, totalizando 462 profissionais de nível superior nessas 4 carreiras. Nas duas décadas anteriores o Banco havia contratado 183 profissionais dessas áreas, o que não corresponde sequer à metade das vagas abertas nos anos 1970. A necessidade de profissionais era tamanha que o BNDE contratou, no início da década de 1970, uma série de estagiários para cobrir o deficit de pessoal. Quando esses estagiários concluíam a graduação, o Banco não podia abrir mão da presença desses jovens profissionais treinados internamente, conhecedores da máquina e dos procedimentos operacionais. Por essa razão, foi criada a categoria de adestrando para os estagiários que já tinham se formado, muitos dos quais fizeram concursos e foram admitidos nos anos seguintes.

Também os editais e o conteúdo das provas de seleção foram alterados nos anos 1970. Em 1972 e 1973 são feitos dois processos seletivos para cobrir as lacunas deixadas pelos 5 anos sem renovação. O processo seletivo de 1972 passou a incluir uma prova de conhecimentos gerais, que versava sobre "os fatos nacionais e internacionais que tenham sido divulgados pelas vias normais de comunicação (jornal, rádio, televisão, cinema, revistas, etc.)" e uma prova de econometria. Foram mantidos os exames de economia, estatística e a prova de análise e avaliação de projetos. Em 1973, adicionou-se uma prova de matemática financeira. As provas para engenheiros dos anos de 1972 e 1973 deixaram de ser divididas por setores, passando a exigir simplesmente que o profissional tivesse conhecimentos gerais nas áreas de "análise de investimentos e de projetos, análise de custos, contabilidade geral, estatística, e métodos de pesquisa operacional”. Nesse sentido, houve um pequeno e breve retrocesso no grau de especialização exigido dos candidatos. Acentuou-se, em contrapartida, a tendência à matematização, que favorece o perfil técnico e a capacidade operacional dos candidatos, com a inclusão de exames de econometria e matemática financeira.

A maior abrangência das provas e o fim da segmentação dos candidatos foi radicalmente revertida nos processos seletivos feitos depois da conclusão da 
consultoria realizada pela Booz-Allen Hamilton. Os exames passaram a apresentar um enfoque ainda mais prático e setorial do que aquele esboçado em meados dos anos 1960. No ano de 1975 foi adicionada uma cláusula requisitando ao menos cinco anos de experiência profissional na área para a qual o candidato concorria. Tal exigência parece advir da necessidade do Banco de incorporar pessoas que já tivessem treinamento especializado para suprir a lacuna de profissionais, que se acentuara devido ao aumento das funções desempenhadas pelo Banco no II PND. Os exames de conhecimentos gerais deixaram de existir e mesmo a prova teórica foi suprimida, sendo o candidato avaliado por um trabalho prático e por uma entrevista centrada no tema de especialidade escolhido.

No caso da prova aplicada, os economistas puderam optar pelas áreas de: 1) Análise econômica de projetos, 2) Mercado de capitais, 3) Planejamento econômico e 4) Estudos setoriais. Já os engenheiros tiveram as seguintes opções: 1) Projetos para indústrias químicas e petroquímicas, 2) Projetos para indústrias de papel e celulose, 3) Projetos para indústrias de siderurgia, metalurgia e mineração, 4) Projetos para indústrias mecânicas, 5) Projetos para indústrias de bens de capital, 6) Projetos para indústrias de infraestrutura, 7) Projetos para agropecuária e 8) Projetos para abastecimento. Também exigiam-se conhecimentos gerais sobre elaboração, análise, implantação e acompanhamento de projetos específicos, engenharia econômica, administração da produção, orçamento de investimentos, equipamentos e tecnologia específica, poluição e preservação do meio ambiente, entre outros. Houve, pois, uma acentuação sem precedentes na orientação setorial e no caráter aplicado do exame de seleção, que decorreu da estrutura setorial que o Banco adotou para executar o II PND (Mourão, 1994, p. 5).

Em 1976, as áreas de especialidade contempladas no exame mudaram. A primeira transformação notável foi o fim da separação entre engenheiros e economistas, podendo cada candidato optar pela área com a qual tivesse maior familiaridade, independentemente de sua formação original. As opções que apresentavam-se aos economistas e engenheiros passaram a ser: 1) Administração e análise financeira, 2) Mercado de capitais, 3) Análise microeconômica de projetos, 4) Planejamento econômico e 5) Análise técnica de projetos.

A seleção de 1979, por fim, foi aberta apenas ao pessoal interno que precisava passar por concursos, entre os quais os estagiários e adestrandos. Esse é o primeiro ano em que houve uma bibliografia e tópicos de estudo indicados aos candidatos. A área de mercado de capitais ocupou cinco das dez páginas de pontos recomendados aos economistas, e também metade do programa do exame para os engenheiros. Para que se tenha uma medida de comparação, o segundo maior 
ponto do programa para economistas, planejamento, ocupou menos de duas páginas. Conclui-se, portanto, que a tendência de reforço da área financeira, que teve início com a inclusão do exame de matemática financeira, em 1973, acentuou-se ao longo da década, passando pela seleção de especialistas para as áreas de mercado de capitais e análise financeira em 1975-1976, até em 1979 ocupar metade do programa da seleção. Esse novo enfoque foi certamente indissociável da criação das três subsidiárias voltadas à atuação do Banco no mercado de capitais em 1974 (BNDES, 2002, p. 95-96 e 101).

\title{
UMA DÉCADA E MEIA PERDIDA: 0 BNDES EM BUSCA DE UM NOVO PARADIGMA, CON- CURSOS ESTAGNADOS (1980-1993)
}

\begin{abstract}
Durante muito tempo, o recrutamento de pessoal [para as subsidiárias], através de avaliação de currículo e provas específicas, sem um concurso público, e o oferecimento de salários mais altos que atraíssem esses profissionais foram pontos de divergência dentro do Banco [...]. As subsidiárias haviam passado por uma dura experiência no início da década de 80, durante a gestão de Luís Sande, quando os parâmetros de recrutamento das subsidiárias foram substituídos por práticas patrimonialistas, o que gerou, inclusive, um fortalecimento do movimento sindical dentro do Banco. A partir dessa experiência, todos passaram a concordar que o concurso público era a melhor alternativa para o recrutamento de pessoal (Lima, 2006, p. 88).
\end{abstract}

Os anos 1980 correspondem a um período de crise do modelo de desenvolvimento por substituição de importações e da industrialização acelerada que prevaleceu, com algumas oscilações, do governo Vargas ao governo Geisel. A instabilidade econômica, o descontrole monetário, o crescente volume da dívida externa e interna e os sucessivos planos de combate à inflação provocaram a queda nos investimentos estatais e privados. O crescimento do PIB caiu de uma média de $6,8 \%$ nos anos Geisel para $2 \%$ de crescimento médio nos anos do governo João Figueiredo (ABreu, 1990). Mesmo que o BNDE não tenha experimentado uma redução de seu orçamento correspondente à queda da atividade econômica, é possível argumentar que ele ficou politicamente à deriva.

O primeiro presidente do BNDE do governo João Batista Figueiredo, Luiz de Oliveira Sande, era advogado e administrador e havia sido secretário da Fazenda da Prefeitura de Salvador e secretário da Fazenda do Estado da Bahia nas gestões de Antonio Carlos Magalhães. Sande ocupou a presidência do BNDE de março 
de 1979 a setembro de 1983 e foi substituído por outro homem de ACM, Jorge Lins Freire, que tinha sido assessor-chefe de Sande na Secretaria da Fazenda da Bahia e assumiu o posto de secretário com a saída de Sande ${ }^{11}$. A indicação desses presidentes teria sido resultado de concessões de Figueiredo às lideranças regionais que o apoiavam (Vianna, 2010, p. 306; Lima, 2006, p. 109). Não é apenas no depoimento de Marco Antonio Lima que se avalia essa gestão como patrimonialista: em entrevistas com ex-diretores do Banco, realizadas entre 2012 e 2015, foram usadas as expressões: "um presidente que trouxe uns assessores esquisitos, chamado Luiz Sande", "foi o pior presidente da história do BNDES", "tentou efetivamente transformar o Banco em uma instituição que seguisse os seus interesses políticos". Chegou-se ao ponto de dizer que ele consagrava-se à "busca mesquinha de interesses particulares"12.

O panorama foi, então, de crise política interna e colapso da possibilidade do Banco de exercer a sua função de financiador do desenvolvimento em uma economia que desaquecia, na qual as empresas sequer tinham condições de honrar as dívidas contraídas. No início, o BNDE empenhou-se em apoiar empresas consideradas estratégicas, sanear suas finanças e, assim, evitar maiores danos. Ao poucos, os técnicos passaram a se perguntar, novamente, qual deveria ser o foco de sua atuação no novo contexto, razão pela qual procuraram organizar um processo de planejamento estratégico interno. O comitê de planejamento foi formado pelos chefes de departamento e superintendentes do Banco. Eles procuravam fazer uma política de dentro para dentro, excluindo a direção que rejeitavam. A instabilidade administrativa era tamanha que os técnicos sequer conseguiram debater suas propostas com a diretoria. Continuaram, então, eles próprios, com seu planejamento interno. Passaram a delinear possíveis cenários para a economia brasileira no período 1983-1986 e, a partir deles, pensar que estratégias o Banco poderia adotar para ajudar a refazer a economia no pós-crise. Primeiro, orientaram-se por um cenário que chamaram de "Retomada", no qual a economia voltaria a crescer, capitaneada pelo empreendimento privado. Nesse cenário o investimento estatal e a perspectiva setorial perderam foco. As palavras de ordem passaram a ser modernização para aumentar a competitividade, tecnologia e expansão da fronteira agrícola (MouRÃo, 1994, p. 5-11). Outra inflexão nas prioridades decorreu da criação, em 1982, de uma área social que alterou o nome do BNDE para BNDES. Tal inflexão não resultou de uma iniciativa própria do Banco, e sim da decisão

11 Ver DHBB: verbetes Luiz Sande e Jorge Lins Freire. Disponível em: http://cpdoc.fgv.br/acervo/ dhbb.

12 Entrevista concedida à autora em 2012. 
federal de alocar nele o Fundo de Investimento Social (FINSOCIAL), destinado a financiar projetos de cunho assistencial nas áreas de saúde, educação, habitação popular e pequena agricultura (TAVARES, 2010, p. 183).

Os anos de crise e caos e o fim do enfoque setorial impactaram também os concursos. O Banco ficou de 1979 a 1983 sem ter nenhum processo de seleção para as quatro carreiras em consideração. Em 1984, o concurso passou a ser estruturado em um exame dividido em duas etapas, uma objetiva e uma discursiva, formato que prevalece até hoje. O conteúdo das duas etapas era o mesmo. No caso dos economistas: microeconomia, macroeconomia, economia internacional, economia brasileira, análise e avaliação de projetos, contabilidade, matemática financeira e estatística. No caso dos engenheiros: análise de investimentos, contabilidade, finanças, administração da produção, microeconomia, pesquisa operacional, estatística e tecnologia. O exame aboliu qualquer tipo de segmentação setorial. Deixou-se de exigir que os engenheiros tivessem conhecimentos especializados, e a única área propriamente ligada a engenharia que se sobressaiu foi a tecnologia, que havia sido considerada essencial no cenário e planejamento de 1983. De resto, o conhecimento requerido dos engenheiros pouco diferiu da formação de economistas ou administradores.

Em 1988 chegou-se a promulgar um edital para a contratação de profissionais de nível superior, que foi suspenso devido às medidas de contenção de gastos federais lançadas pela Presidência da República dez dias depois da publicação do edital. Desde 1986, os funcionários do Banco estavam engajados na preparação de um segundo cenário para orientar suas atividades. Esse cenário foi batizado de "Integração Competitiva" e postulou que a substituição de importações era uma etapa encerrada, o país deveria enxugar o Estado que era incapaz de dinamizar o crescimento, o capital estrangeiro contribuiria para a modernização tecnológica e gerencial da economia, e que, portanto, o Brasil deveria integrar-se ao mercado mundial, expondo suas firmas à competição internacional (MouRÃo, 1994, p. 13-19).

Na gestão de Márcio Fortes (1987-1989), um empresário do ramo da engenharia civil e herdeiro de uma grande construtora, a BNDESPar, começou a vender ações das empresas que controlava. Esse primeiro movimento de autoprivatização resultou na venda de 17 empresas. O que começou como uma venda de ativos para desonerar o Banco da tarefa de administrar diretamente as empresas que passara a gerir para salvar da crise, e para permitir que ele reciclasse seu capital, tornou-se o paradigma de privatização empregado pelas gestões federais subsequentes (VELASCO JR., 2010, p. 312-315). A perspectiva da integração competitiva que começara a conquistar o BNDES na segunda metade dos anos 1980 se consolidou e se 
espraiou com a chegada, em 1990, de Fernando Collor à Presidência da República e de Eduardo Modiano, engenheiro com pós-graduação em administração pelo MIT, à presidência do BNDES. Nesse momento, o ideário de modernização, competitividade e integração internacional abraçado internamente colou-se ao discurso do novo governo, que encarregou o Banco do Programa Nacional de Desestatização, trazendo-o de volta ao centro do palco, não para planejar o desenvolvimento, mas para remodelar a estrutura de controle da economia do país (Modiano, 2000, p. 324; Costa, 2011, p. 33-35).

É possível dizer que a obsessão dos anos 1990 pelo enxugamento da máquina pública atingiu o próprio BNDES, já que, no governo Collor, o banco experimentou pela primeira vez um substantivo declínio em seu orçamento; da estabilidade na faixa dos 7.000.000 mil dólares ao ano desde a redemocratização, caiu para uma média de 5.000.00o mil dólares ao ano (PROCHNIK, 1995, p. 165). Ademais, a política de enxugamento fez com que nos dez anos cobertos pelos governos José Sarney, Itamar Franco e Fernando Collor, o Banco realizasse apenas um concurso, em 1992, sem notáveis modificações em relação ao edital de 1984. No total, entre 1980 e 1993, contrataram-se 129 profissionais, 14 contadores, 30 economistas, 34 engenheiros e 51 advogados. Tal número de admissões não equivale sequer ao volume de contratações dos primeiros 20 anos, correspondendo a 94\% das admissões entre $1952-1971$ e a $15 \%$ entre $1972-1979^{13}$.

A estagnação no fluxo de entrada de profissionais teve efeito três décadas depois, quando a geração contratada nos anos 1970 começou a aposentar-se, fazendo com que o Banco tivesse que enfrentar o desafio de transmitir rapidamente as competências e o espírito de corpo da instituição para um grande grupo de recém-contratados. Outra alteração visível no período 1980-1993 é o crescimento da proporção de advogados entre os contratados, que ultrapassou pela primeira vez o volume de admissões para as outras carreiras. Essa mudança pode ser relacionada à instauração do Programa Nacional de Privatização, que contava com um comitê jurídico para operar leilões, fazer auditorias, licitar, desenhar contratos etc. (CostA, 2011, p. 44-45). A prevalência dos advogados foi preservada nos 20 anos seguintes ${ }^{14}$.

13 O cálculo foi feito equiparando o número de anos para dar comparabilidade aos valores e poder extrair os percentuais.

14 Os funcionários de carreira que chegaram à diretoria do Banco nos últimos vinte anos, quase todos engenheiros e economistas, foram recrutados essencialmente na coorte de 1970. É possível indagar se o crescimento do número de advogados no Banco, a partir dos anos 1980, terá efeitos sobre a carreira de origem dos futuros diretores. 


\section{FORMA ESTÁVEL, CONTEÚDO VARIÁVEL: A BIBLIOGRAFIA DOS CONCURSOS COMO INDICADOR DAS TRANSIÇÕES NAS PRIORIDADES DO BANCO (1994-2012)}

Entre 1994 e 2012 o Banco contratou 777 advogados, 569 engenheiros, 479 economistas e 337 contadores, totalizando 2162 profissionais. Equiparando-se o número de anos, o volume de admitidos nos concursos da década de 1970, até então a mais pujante, correspondeu a apenas $41 \%$ dos recrutados nesse último período. Até 2012 os concursos mantiveram o modelo implementado em 1984, no qual o exame era divido em etapa objetiva e etapa discursiva. Mudaram, entretanto, os conteúdos avaliados em cada uma dessas etapas. Em 1997 foi incluído na seleção um exame de língua inglesa, o que coincide com a transferência para o BNDES do programa de apoio à exportação, antes gerido pela FINAME. Em 2001, seguindo a tendência de aprofundamento da cooperação sul-americana, o candidato passou a poder optar entre inglês e espanhol. Nesse mesmo ano incluiu-se um exame de noções de informática. Em 2005, a prova de informática desaparece e a parte objetiva do exame passa a contemplar questões de língua portuguesa, língua espanhola ou inglesa e conhecimentos específicos. Enquanto isso, a prova discursiva continuou a examinar apenas conhecimentos específicos.

Para analisar as mutações dos concursos dos últimos anos será discutida a lista de referências bibliográficas recomendadas nos editais de seleção para engenheiro dos concursos de 1997, 2001 e 2008, e para economista dos anos de 1997, 2002, 2005, 2007 e 2009. O índice $\mathrm{JEL}^{15}$, desenvolvido pela American Economic Association e internacionalmente adotado para classificar a produção de conhecimento em economia, foi o parâmetro adotado para organizar os títulos indicados aos candidatos. A possibilidade de usar o indicador de bibliografia econômica para classificar também a literatura recomendada aos engenheiros é, em si, uma evidência sobre o tipo de engenheiros atraído para a instituição.

Na bibliografia recomendada aos economistas no edital de 1997, os temas de maior incidência são relativos à formação geral dos candidatos. É possível correlacionar o tema "macroeconomia e economia monetária" à questão primordial da economia de meados dos anos 1980 a meados dos anos 1990, que era a estabilização monetária. No início do governo Fernando Henrique Cardoso, o BNDES estava imerso nas tarefas de promover os ajustes e reformas propostas pelo Plano Real e continuou atuando como agente condutor da privatização, que passou a contem-

15 Disponível em https://www.aeaweb.org/econlit/jelCodes.php?view=jel. Consultado em: 19/10/2015. 
Tabela 1. Classificação JEL da Bibliografia dos Editais de Concurso para as Carreiras de Economista e Engenheiro do BNDES.

\begin{tabular}{|l|c|c|c|c|c|c|c|c|c|c|}
\hline $\begin{array}{c}\text { Índice JEL de classificaç̧̃̃o } \\
\text { da produção em Ciência } \\
\text { Econômica }\end{array}$ & 1997 & 2002 & 2005 & 2007 & 2009 & Total & 1997 & 2001 & 2008 & $\begin{array}{c}\text { Ecotal } \\
\text { Toco }\end{array}$ \\
\hline $\begin{array}{l}\text { (A) Ciência Econômica } \\
\text { Geral e Ensino de Economia }\end{array}$ & $3,1 \%$ & & & $0,6 \%$ & $6 \%$ & $1 \%$ \\
\hline
\end{tabular}

(B) História do Pensamento

Econômico, Metodologia e

Abordagens Heterodoxas

(C) Métodos Quantitativos e

Matemáticos

\begin{tabular}{|l|l|l|l|l|l|l|l|l|l|}
\hline $8,3 \%$ & $6,3 \%$ & $5,3 \%$ & $6,1 \%$ & $11,5 \%$ & $6,4 \%$ & $11 \%$ & $6 \%$ & $7 \%$ & $8 \%$ \\
\hline $8,3 \%$ & $3,1 \%$ & $2,6 \%$ & $4,1 \%$ & $7,7 \%$ & $7,0 \%$ & & & $4 \%$ & $1 \%$ \\
\hline $16,7 \%$ & $3,1 \%$ & $7,9 \%$ & $6,1 \%$ & $3,8 \%$ & $7,0 \%$ & & & $4 \%$ & $1 \%$ \\
\hline
\end{tabular}

(D) Microeconomia

(E) Macroeconomia e

Economia Monetária

$\begin{array}{lllllll}8,3 \% & 15,6 \% & 5,3 \% & 4,1 \% & 3,8 \% & 7,0 \%\end{array}$

(F) Economia Internacional

(G) Economia Financeira

$8,3 \%$

$9,4 \%$

Público
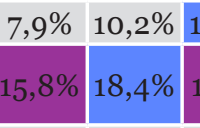

\begin{tabular}{|l|l|l|l|}
$114 \%$ & $17 \%$ & $11 \%$ & $14 \%$ \\
\hline
\end{tabular}

(I) Saúde, Educação e Renda

\begin{tabular}{l|l|l|l}
$5,3 \%$ & $4,1 \%$ & $7,7 \%$ & $3,5 \%$
\end{tabular}

(J) Economia do Trabalho e

da Demografia

\begin{tabular}{l|l}
$2,6 \%$ & $0,6 \%$
\end{tabular}

(K) Direito e Economia

$\begin{array}{lllllll}\text { (L) Organização Industrial } & 8,3 \% & 3,1 \% & 7,9 \% & 8,2 \% & 7,7 \% & 7,0 \%\end{array}$

(M) Administração de

Negócios e Economia de Negócios: Marketing,

Contabilidade e Economia

da Gestão de Pessoal

(N) História Econômica

(2)

\begin{tabular}{l|l|l|l}
$8,3 \%$ & $3,1 \%$ & $2,6 \%$ & $2,0 \%$
\end{tabular}

\begin{tabular}{l|l|l|}
$2,9 \%$ & $14 \%$ & $17 \%$
\end{tabular}

$4 \% \quad 4 \%$

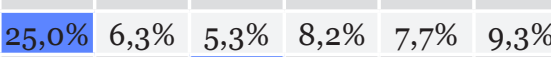

(O) Economia do

Desenvolvimento, Inovação,

Mudança Tecnológica e

\begin{tabular}{l|l|l|l|l|l}
$8,3 \%$ & $6,3 \%$ & $18,4 \%$ & $10,2 \%$ & $3,8 \%$ & $9,9 \%$
\end{tabular}

$4 \%$

Crescimento

(P) Sistemas Econômicos

(Q) Economia da

Agricultura e dos Recursos

Naturais, Economia da

Ecologia e Meio Ambiente

(R) Economia Urbana,

Rural, Regional, Imobiliária

e dos Meios de Transporte

(Y) Categorias Mistas

(Z) Outros tópicos

(decretos e publicações

governamentais)

(ว) Tópicos de Engenharia:

ciência dos materiais, física, química, eletrotécnica

Total

$\begin{array}{llllllllllll}100 & 100 & 100 & 100 & 100 \% & 100 \% & 100 \% & 100 \% & 100 \% & 100 \% & 100 \%\end{array}$

Legenda: Azul: tema mais presente no ano. Roxo: segundo tema mais presente. Fonte: editais de seleção e listas de admissão para o BNDE(S) de 1997 a 2009, fornecidos pelo Serviço de Informação ao Cidadão do BNDES. Elaboração: classificação, tradução do índice e elaboração própria. 
plar os setores de energia, telecomunicações, minérios, dentre outros. Na segunda metade dos anos 1990, depois de um ciclo de aproximadamente dez anos orientado para o esforço de estabilização, reestruturação do Estado e abertura internacional, o Banco voltou a engajar-se em políticas de fomento industrial.

O Banco intensificou o apoio à diversificação dos investimentos e voltou a sustentar, em parceria com grupos privados nacionais e estrangeiros, fortes inversões em infraestrutura [...]. Além disso, o crescimento da confiança nos parâmetros fundamentais da economia nacional, em consequência do processo de estabilização, vem resultando no aumento dos investimentos em empreendimentos industriais e de agropecuária, em especial naqueles que envolvem projetos de reestruturação competitiva e de atualização tecnológica das plantas produtoras (Luiz Carlos Mendonça de Barros, Mensagem do Presidente, BNDES, Relatório Anual, 1997).

Para a volta do BNDES ao segmento industrial - com o objetivo prioritário de "contribuir para a modernização e a internacionalização bem-sucedida da economia brasileira através do financiamento ao comércio exterior, da reestruturação da indústria e do incentivo ao incremento da competitividade empresarial" (BNDES, Luiz Carlos Mendonça de Barros, Discurso de posse na presidência, 1995) - foi fundamental a chegada de Luiz Carlos Mendonça de Barros à presidência do Banco. Ele provinha de um grupo dentro do governo FHC que pretendia conciliar liberalismo e desenvolvimentismo, ou seja, estabilização e medidas de fomento a um sistema produtivo inserido em um contexto internacional (SALLUM, 1999, p. 34-35; BNDES, Luiz Carlos Mendonça de Barros, Discurso de posse na presidência, 1995).

Ainda que todas as leituras recomendadas aos engenheiros em 1997 estivessem presentes em 1992, a proporção dos temas foi alterada, já que diversos títulos foram suprimidos. É possível observar que, em 1997, prevalecem textos das áreas de organização industrial e desenvolvimento, inovação, mudança tecnológica e crescimento. As novas atividades do BNDES foram viabilizadas pelo aumento de seu orçamento, que praticamente dobrou, ano a ano, na gestão Mendonça de Barros. Passou de 6,7 bilhões de reais em 1994 a 40,4 bilhões de reais em 1997, e manteve-se nesse patamar até 2002. A principal fonte de incremento dos recursos do Banco no final do governo FHC foi um repasse do tesouro de quase 10 bilhões, aliado a um aumento na captação de recursos em organizações internacionais. Com isso, o orçamento do Banco passou de 43,3 bilhões de reais em 2001 para 64,4 bilhões de reais em 2002. Tal crescimento teve relação com a participação 
do BNDES no programa emergencial de combate à crise energética que assolara o país na metade de 2001 (Prochniк, 2008; BNDES, Francisco Gros, Discurso de transmissão da presidência, 2002).

Os exames de seleção de 2001 e 2002 foram marcados pelo predomínio de tópicos da área de economia financeira. $\mathrm{O}$ segundo tema de maior incidência foi economia internacional, nos exames para economistas, e administração, marketing, contabilidade e gestão, nos exames para engenheiros. Francisco Gros, em seu discurso de transmissão de cargo, explicou ter priorizado em sua gestão 2000-2001 "o fortalecimento do mercado de capitais, o apoio aos segmentos da economia que detém vantagens competitivas no mundo globalizado e a necessidade de enfrentarmos o desafio de criarmos os global players neste país" (BNDES Francisco Gros, Discurso de transmissão da presidência, 2002). Eleazar de Carvalho, presidente de 2002, detalha essa orientação quando diz em seu discurso de encerramento que

Tem sido fundamental para o Banco manter abertos e desenvolver novos mecanismos de captação de mercado. A política de riscos de crédito desta instituição nos últimos anos tem sido a de conciliar prazos e taxas, além de adequar as provisões para garantir a sustentabilidade e retorno das operações. Retorno este compatível com outras instituições semelhantes no mundo. Preservar a qualidade do crédito e o rating do BNDES é aumentar a sua capacidade de apoio às prioridades do Banco (BNDES, Eleazar de Carvalho Filho, discurso de transmissão da presidência, 2003).

Gros e Eleazar de Carvalho fizeram integralmente a sua educação superior nos Estados Unidos e tiveram longa trajetória no mercado financeiro: antes de entrar no BNDES, Gros trabalhou no grupo financeiro Metropolitana, na corretora de valores Kidder, Peabody and Co., no Unibanco, no BFC Banco S.A e Morgan Stanley; Eleazar trabalhou no Crefisul/Citibank, no Banco Garantia e no UBS-Warburg. Em suas gestões, implementaram processos seletivos com o objetivo de recrutar profissionais com a expertise financeira, administrativa e em economia internacional necessárias ao engajamento na financeirização e na internacionalização, para o qual encaminhavam o Banco e o país.

O concurso de 2005 ocorreu em um contexto de reversão desse ideário. O presidente que assumiu o Banco em 2003, Carlos Lessa, que fora professor da Unicamp e da UFRJ e funcionário da CEPAL, atacou frontalmente essa orientação em seu discurso de posse afirmando que: 
O Banco, comprometido com o que é novo, não se subordina ao jogo de mercado. Não pode ter atitude passiva em relação aos sinais de mercado. [...]. O banco de desenvolvimento é uma instituição vital para um país periférico que sonha superar o atraso. É literalmente um construtor de mercados e articulações produtivas. Contrasta com o banco de investimento que assume o risco como critério dominante. [...]. O banco de desenvolvimento inclui em uma missão muito mais ampla e complexa as recomendações típicas de um banco de investimento; porém se delas se tornar serventuário, cancela seus propósitos maiores (BNDES, Carlos Lessa, discurso de posse na presidência, 2003).

Ainda que o tom de enfrentamento observado em 2003 não tenha se arrastado até 2005, o presidente que assumiu no final de 2004, o sociólogo, economista e militante do PT Guido Mantega, deixou claro em seu primeiro relatório administrativo que o BNDES deveria "prosseguir, em 2005 e nos anos seguintes, a trajetória que se traçou ainda no início do atual governo, quando abandonou a fugaz experiência de banco de investimento para retomar, com uma visão atualizada do Brasil e do mundo, o destino histórico de ser o banco de desenvolvimento de todos os brasileiros" (Guido Mantega, in: BNDES, Relatório Anual 2004, p. 12). Para tanto, Mantega propôs que o Banco fizesse "investimentos em inovação e infraestrutura, fundamentais para o aumento de competitividade do país num momento em que a inserção brasileira na globalização tem de ser a de ativo protagonista e não a de mero espectador ou modesto coadjuvante" (Guido Mantega, in: BNDES, Relatório Anual 2005, p. 8). É coerente com essa perspectiva a inflexão na bibliografia exigida no concurso de 2005 para economistas, que passou a concentrar-se na área de Economia do Desenvolvimento, Inovação, Mudança Tecnológica e Crescimento e na economia do setor público.

Em 2007 teve início a presidência do economista Luciano Coutinho, que foi professor da USP e da Unicamp, consultor privado e que, em novembro de 2015, atingiu o marco de 8 anos e meio à frente da instituição, equiparando-se à gestão mais longa do Banco até então, a de Marcos Vianna. O número de vagas oferecidas nos concursos de seleção para o Banco na gestão Coutinho correspondeu a um terço do total das vagas abertas pelo Banco em seus sessenta anos. A proliferação dos concursos coincidiu com a ampliação dos ativos do Banco, que mais do que triplicaram de 2007 a 2012, com a intenção de socorrer as empresas afetadas pela crise e de promover políticas anticíclicas. Para evitar que a rápida renovação de quadros pudesse comprometer a transmissão da memória e dos valores da instituição, deu-se início em 2010 ao Projeto Valores, no qual os recém-contratados 
entravam em contato com os funcionários das gerações anteriores, tomavam conhecimento da história institucional e participavam do processo de definição do conjunto de princípios que deveriam orientar a instituição nos próximos anos (BNDES, Relatório Anual, 2010, 2011 e 2012).

Nos concursos da gestão Coutinho, em 2007, 2008 e 2009, a proeminência das áreas de economia do setor público, dos textos de legislação e de enunciados dos programas do governo teve relação com a forte participação do Banco na viabilização dos planos do governo federal no âmbito do Programa de Aceleração do Crescimento (PAC) e das Políticas de Desenvolvimento Produtivo. Nas palavras do presidente do Banco:

Não é demais sublinhar que a execução do PAC é condição imprescindível para crescer. Não há dúvida de que investimentos em infraestrutura - prioritariamente energia e sistema viário - precisam ser acelerados. Para isso, além da poupança pública, é decisiva a participação do setor privado. O BNDES dará suporte proativo à necessária coordenação entre empreendedores, bancos e o mercado de capitais na estruturação de funding adequado, especialmente para os projetos de maior porte (BNDES, Luciano Coutinho, discurso de posse na presidência, 2007).

A parcela da literatura sobre a área financeira na bibliografia recomendada cresceu de 2005 a 2009, tendo chegado no exame de economia de 2009 a ser a área de maior incidência. Não teve, entretanto, metade do peso do ano 2002, mesmo em um cenário de crise financeira global, no qual o Banco precisou engajar-se na reestruturação patrimonial das empresas atingidas pelo cenário adverso. Os temas de organização industrial, inovação, meio ambiente e sustentabilidade, economia regional, em destaque no discurso, não tiveram incremento na literatura recomendada aos candidatos quando comparado com os anos anteriores. Os concursos de 2011 e 2012 mantiveram os mesmos procedimentos de avaliação, mas não recomendaram nenhuma literatura específica aos candidatos.

\section{CONCLUSÕES}

A apresentação dos editais dos concursos que o BNDE(S) fez entre 1955 e 2012 e a descrição das modificações nos métodos de seleção e nos conteúdos dos exames permitiram assinalar alterações nas qualificações requeridas aos candidatos selecionados para os postos de nível superior do quadro regular da burocracia do 
Banco, bem como observar a existência de paralelismos entre as mudanças assinaladas e as variações, tanto nas funções desempenhadas pelo BNDE(S), quanto no prestígio e centralidade da instituição no cenário nacional. Algumas reflexões adicionais podem ser propostas a partir dos dados apresentados.

Primeiramente, é possível retomar a ideia de ilha de excelência burocrática e indagar em que medida a existência dos concursos ajuda a criar uma burocracia assemelhada ao tipo ideal weberiano. É plausível argumentar que a seleção por exame ajuda a afastar o patrimonialismo e clientelismo, na medida em que os candidatos são anônimos e julgados de acordo com critérios uniformes. Já a variação no padrão e no conteúdo da seleção pode favorecer diferentes perfis sociais e políticos, ao atrair estudantes provenientes de faculdades distintas, que enfocam áreas de estudos dessemelhantes e recrutam estudantes de camadas sociais diferentes. Um exame que privilegia temas da área de desenvolvimento econômico, inovação, organização industrial poderia favorecer estudantes de faculdades públicas de tradição desenvolvimentista, como a Unicamp e a UFRJ, enquanto um exame centrado em finanças eventualmente atrairia mais candidatos formados em escolas privadas com ênfase em finanças e métodos quantitativos, como a FGV-RJ e o IBMEC. Em uma burocracia que encarregou-se historicamente de planejamento do desenvolvimento, que participou de processos de definição de suas próprias prioridades, que por vezes rejeitou ou driblou ordens endereçadas pela camada de dirigentes politicamente indicados, como analisado em artigo anterior (KLÜGER, 2015), a orientação política e o tipo de formação recebida pelos técnicos têm efeitos sobre as decisões tomadas. Nesse sentido, a burocracia do BNDE(S) estaria longe de ser abstrata e funcionar de acordo com o princípio sine ira ac studio, que suporia "a eliminação do amor, do ódio e de todos os elementos sentimentais, puramente pessoais e, de modo geral, irracionais, que se subtraem ao cálculo, na execução das tarefas oficiais”, como suposto que sejam as burocracias plenamente desenvolvidas delineadas no tipo ideal weberiano (WEBER, 2004, p. 213).

Em segundo lugar, ainda que o recrutamento dito meritocrático possa vedar a burocracia do Banco contra os apadrinhamentos e a seleção de candidatos de acordo com suas orientações políticas e possa proteger os quadros da casa de demissões sumárias de viés político, é possível ver que diferentes estratégias foram usadas para contornar essa barreira, seja o uso das subsidiárias anexas ao Banco como porta de entrada de pessoas da preferência dos diretores indicados, como os funcionários do Banco relataram ter ocorrido no início dos anos 1980, seja a migração das funções do Banco para outros órgãos em que os dirigentes tivessem maior poder de controle sobre o recrutamento, como foi o caso da migração do 
centro decisório do planejamento do BNDE para o EPEA nos anos 1970, seja ainda o deslocamento para posições marginais no interior da instituição daqueles que se apresentaram como adversários dos novos projetos. Assim sendo, os concursos podem até reduzir o impacto da política pura sobre a estrutura da burocracia, mas esta continua achando flancos pelos quais logra interferir não apenas nas diretrizes das políticas feitas pelo Banco, como suposto no modelo weberiano, mas também na composição interna do corpo burocrático, que, no tipo ideal, deveria seguir critérios supostamente racionais, técnicos e universais.

Em terceiro lugar, é possível conjecturar acerca dos efeitos geracionais e cíclicos do recrutamento. Uma série histórica mais ampla eventualmente permitirá avaliar se a mudança nas proporções dos quadros recrutados por carreiras terá efeito sobre o perfil dos diretores recrutados internamente - por exemplo, se haverá mais advogados entre os próximos grupos de dirigentes ou se o prestígio diferenciado das carreiras na sociedade e no interior da burocracia, em um dado momento, é o principal determinante da ascensão interna. Outra questão nessa linha, igualmente dependente de observações de mais longo prazo e profundidade, é: em que medida a convivência dos quadros no interior da burocracia é capaz de dissolver as divergências de origem e criar coesão interna entre coortes recrutadas de acordo com princípios e conteúdos diferentes, que poderiam favorecer visões de mundo distintas? Os cursos de reciclagem internos, as consultorias e os ciclos de repactuação dos valores e orientações do Banco seriam instrumentos eficazes para reconverter e alinhar as gerações em torno de novos projetos?

Finalmente, o estudo dos concursos só reforça a ideia de que há uma grande variedade de estratégias de desenvolvimento e uma correlata maleabilidade no que se entendeu ser a função de um banco de desenvolvimento nacional nos últimos 60 anos. Os exames de seleção passaram por notáveis mutações, que foram desde um modelo aberto de recrutamento baseado em ensaios teóricos pouco especializados, passando por provas puramente técnicas de análise de projetos, chegando a exames que avaliam as competências linguísticas além das técnicas e que, na bibliografia recomendada, podem privilegiar diferentes áreas de atuação do Banco tão diferentes quanto finanças ou organização industrial. Tais alterações mostram o quanto a constância institucional é dada antes pela construção de uma solidariedade e coesão interna da burocracia, continuamente forjada e repactuada, - que procura preservar a instituição de ataques externos e preservar sua autonomia relativa para operar a triagem de projetos e a definição dos financiamentos - do que pela univocidade da função pelo Banco desempenhada, já que esta parece ter se alterado continuamente ao longo da história do BNDE(S). 
O estudo dos concursos apresentado neste artigo e as questões por ele suscitadas fazem parte de um conjunto de análises necessárias para ampliar a compreensão da evolução institucional do Banco e da formação das elites burocráticas de Estado. Pesquisas sobre as características sociais e trajetórias dos funcionários e dirigentes, os canais de acesso aos postos de direção da instituição, a evolução interna das carreiras, as transformações no organograma, a fundação de assistência e previdência social do BNDES, os treinamentos internos oferecidos à burocracia, dentre outras, conjugam-se ao estudo dos concursos na tarefa de adentrar a caixa-preta - formato do prédio do BNDES - que é o edifício Juvenal Osório, na Avenida República do Chile. Análises similares replicadas para outros organismos econômicos do Estado Brasileiro poderiam ajudar a esclarecer quais são as condições institucionais subjacentes à existência das ditas ilhas de excelência burocrática.

\section{AGRADECIMENTOS}

Gostaria de agradecer aos responsáveis pelo Serviço de Informação ao Cidadão do BNDES pela prontidão no fornecimento dos editais, listas de funcionários admitidos por concurso e exames de seleção para o Banco e aos editores da revista Plural, sobretudo no que tange aos comentários e sugestões. Aos professores Sylvia Gemignani Garcia e Alvaro Comim, agradeço todo o apoio e incentivo.

\section{REFERÊNCIAS BIBLIOGRÁFICAS}

ABREU, Marcelo de Paiva (org.). A Ordem do Progresso: cem anos de política econômica republicana 1889-1990. Rio de Janeiro: Elsevier, 1990.

BNDES. BNDES 50 Anos de Desenvolvimento. São Paulo: DBA Artes Gráficas, 2002.

Relatórios Anuais 1997, 2010, 2011 e 2012, disponíveis em: http://www.bndes. gov.br/SiteBNDES/bndes/bndes_pt/Institucional/Relacao_Com_Investidores/ Relatorio_Anual/relatorios_anteriores.html. Consultados em 28/10/2015.

. Editais de seleção e listas de candidatos aprovados para o BNDES 1955-2012, fornecidos pelo Serviço de informação ao Cidadão do BNDES.

BNDES. Discurso de posse na presidência do BNDES Luiz Carlos Mendonça de Barros 1995, Carlos Lessa 2003, Luciano Coutinho, 2007 e Discurso de transmissão da presidência do BNDES Francisco Gros, 2002 e Eleazar de Carvalho Filho, 2003, fornecidos pelo Serviço de informação ao Cidadão do BNDES. 
CABRIA, Juan Vicente Bachiller. El BNDES y las estrategias de desarrollo económico en Brasil. Banca pública de desarrollo, instituciones gubernamentales y trayectorias de intervención estatal (1952-2010). Tese de doutorado em Ciência Política. Universidad de Salamanca. Salamanca, 2012.

CAMPOS, Roberto de Oliveira. A Lanterna na Popa. Rio de Janeiro: Topbooks, 1994.

CARNEIRO, Dionísio Dias. “Crise e Esperança 1974-1980”. In: ABREU, Marcelo de Paiva (org.). A Ordem do Progresso: cem anos de política econômica republicana 18891990. Rio de Janeiro: Elsevier, 1990.

CMBEU. "Relatório da Comissão Mista Brasil-Estados Unidos". In: centro internacional celso furtado de políticas para o desenvolvimento. Memórias do Desenvolvimento, ano 2, n. 2. Rio de Janeiro, 2008, p. 279-336.

COSTA, Karen Fernandes da. Metamorfoses: o papel do BNDES na reordenação da economia brasileira. Tese de doutorado em Ciência Política. Universidade Estadual de Campinas. Campinas, 2011.

D’ARAUJO, Maria Celina Soares. O segundo governo Vargas 1951-1954: democracia, partidos e crise política. São Paulo: Ática, 1992.

D'ARAÚJO, Maria Celina et al. (org.). IPEA 40 anos apontando caminhos: Depoimentos ao CPDOC. Brasília: IPEA, 2005.

EVANS, Peter. Embedded autonomy: states and industrial transformation. New Jersey: Princeton University Press, 1995.

GEDDES, Barbara. Building "State" Autonomy in Brazil. Comparative Politics, v. 22, n. 2, p. 217-235, 1990.

GOUVÊA, Gilda Portugal. Burocracia e Elites Burocráticas no Brasil. São Paulo: Paulicéia, 1994.

KLÜGER, Elisa. Técnicos e políticos nos primeiros anos do BNDE. Cadernos do Desenvolvimento, v. 9, n. 14, p. 59-81, 2014.

. A contraposição das noções de técnica e política nos discursos de uma elite burocrática. Revista de Sociologia e Política, v. 23, n. 55, p. 75-96, 2015.

LIMA, Marco Antonio Albuquerque de Araujo. O Desenvolvimento Inacabado do Brasil: o BNDE e a Convenção do Crescimento de 1952 a 1978. Dissertação de Mestrado em Desenvolvimento, Agricultura e Sociedade. Universidade Federal Rural do Rio de Janeiro. Seropédica, 2006.

LOUREIRO, Maria Rita; ABRUCIO, Fernando Luiz. Burocracia e política na nova ordem democrática brasileira: o provimento de cargos no alto escalão do governo federal (governos Sarney, Collor, Itamar Franco e FHC). Relatório de pesquisa. Núcleo de Pesquisas e Publicações, EAESP/FGV, 1998. 
LOPES, Lucas. Memórias do desenvolvimento. Rio de Janeiro: Centro da Memória da Eletricidade no Brasil, 1991.

MARTINS, Luciano. Estado Capitalista e Burocracia no Brasil pós-64. Rio de Janeiro: Paz e Terra, 1985.

MODIANO, Eduardo. "Um Balanço da Privatização nos anos 90". In: PINHEIRO, Armando Castelar; FUKASAKU, Kiichiro (orgs.). A Privatização no Brasil: o caso dos serviços de utilidade pública. Rio de Janeiro: BNDES, 2000.

MOURÃO, Julio Olimpio Fusaro. A Integração Competitiva e o Planejamento Estratégico no Sistema BNDES. Revista do BNDES, v. 1, n. 2, p. 3-26, 1994.

NUNES, Edson de Oliveira. Bureaucratic insulation and clientelism in contemporary Brazil: uneven state-building and the taming of modernity. Tese de doutorado em Ciência Política. University of California. Berkeley, 1984.

OLIVIERI, Cecília. Política, Burocracia e Redes Sociais: as nomeações para o alto escalão do Banco Central do Brasil. Revista de Sociologia e Política, n. 29, p. 147-168, 2007. Os Controles Políticos sobre a Burocracia. Revista de Administração Pública, v. 45, n. 5, p. 1395-1424, 2011.

PROCHNIK, Marta. 1995. Fontes de Recursos do BNDES. Revista do BNDES, v. 2, n. 4 , pp. 143-180, 1995.

PROCHNIK, Marta; MACHADO, Vivian. Fontes de Recursos do BNDES 1995-2007. Revista do BNDES, v. 14, n. 29, p. 3-34, 2008.

SALLUM JR, Brasílio. O Brasil sob Cardoso: neoliberalismo e desenvolvimentismo. Tempo Social Revista de Sociologia da USP, v. 11, n. 2, p. 23-47, 1999.

SCHNEIDER, Ben Ross. Politics within the state: elite bureaucrats and industrial policy in authoritarian Brazil. Pittsburgh: University of Pittsburgh Press, 1991.

SOLA, Lourdes. Ideias econômicas, decisões políticas: desenvolvimento, estabilidade e populismo. São Paulo: Editora da Universidade de São Paulo/Fapesp, 1998.

TAVARES, Maria da Conceição (Org.). Memórias do Desenvolvimento, Centro Celso Furtado, v. 4, n. 4, 2010.

VELASCO JR., Licínio. A Privatização no Sistema BNDES. Revista do BNDES, n. 33, p. 307-382, 2010.

VIANNA, Marcos Pereira. Entrevista concedida a Ângela Coronel, Ricardo Weiss e Marcelo Aveburg em 18 de fevereiro de 1982. Memórias do Desenvolvimento, Centro Celso Furtado, v. 3, n. 3, pp. 65-98, 2009.

WEBER, Max. Economia e Sociedade: fundamentos da sociologia compreensiva, $v$. 2. Brasília: Editora UNB, 2004. 
Anexo: Lista com os títulos recomendados nos editais divididos por ano e por categoria, explicitando as escolhas feitas no processo de classificação utilizado para a construção da Tabela 1.

Economistas: (A) 2002: Sen. (C) 1997: Wonnacot. 2002: Puccini, Wonnacot. 2005: Puccini, Wonnacot. 2007: Guajarati, Puccini, Wonnacot. 2009: Bussab, Guajarati, Puccini. (D) 1997: Ferguson. 2002: Varian. 2005: Varian. 2007: Pindyck, Varian. 2009: Pindyck, Varian. (E) 1997: Dornbush, Simonsen. 2002: Dornbush. 2005: Dornbush, Pereira, Blanchard. 2007: Blanchard, Dornbush, Pereira. 2009: Blanchard. (F) 1997: Williamson. 2002: Gonçalves, Krugman, Gonçalves [2], Kasznar, Aronovich. 2005: Gonçalves, Krugman. 2007: Gonçalves, Krugman. 2009: Gonçalves. (G) 1997: Ayres 1997. 2002: Fabozzi, Fortuna, Brealey, Damodaran, Lethbridge, Sifert, Borges, Altman, Arcoverde, Jorion, Silva. 2005: Fortuna, Brealey, Carvalho. 2007: Brealey, Carvalho, Fortuna, Lima, Ross. 2009: Carvalho, Damodaran, Lima, Ross. (H) 2002: Além, Finnerty, Pires. 2005: Além, Bononi, Finnerty, Rezende, BNDES/BID/MRE, Pasin, Nascimento. 2007: Além, Bononi, Brito, Clemente, Finnerty, Nascimento, Pinto, Rezende, Teixeira. 2009: Além, Ferreira, Finnerty. (I) 2005: Dedecca, Rocha. 2007: Rocha, Singer. 2009: Barros, Rocha. (J) 2005: Ross. (L) 1997: Sherer. 2002: Porter. 2005: Kupfer, Coutinho, Porter. 2007: Coutinho, Kupfer, Laplane, Porter. 2009: Ferraz, Kupfer. (M) 1997: Iudibicus. 2002: Iudibicus. 2005: Iudibicus. 2007 Iudibicus. (N) 1997: Abreu, Velloso, Faro. 2002: Abreu, Giambiagi. 2005: Abreu, Giambiagi. 2007: Abreu, Castro, Giambiagi, Tavares. 2009: Abreu, Giambiagi. (O) 1997: Melnick. 2002: Woiler, Sen. 2005: Woiler, Medeiros, Stiglitz, Belluzzo, Alves, Lall, Ocampo. 2007: Belluzzo, Lall, Medeiros, Ocampo, Stiglitz. 2009: Tigre. (Q) 2005: May. 2007: May. 2009: May. (R) 2005: Diniz, Cano. 2007: Cano, Diniz. 2009: Diniz. (Z) 2002: Bacen, Bacen [2]. 2005: Bacen, MIDC. 2007: MIDC, Ministério do Planejamento, Bacen, Pintec, BNDES, PAC. 2009: MCT, PDP, PAC.

Engenheiros: 2001: Sen. (C) 1997: Faro, Wonnacot, Polya. 2001: Wonnacot. 2008: Morettin, Puccini. (D) 2008: Varian. (E) 2008: Mankiew. (G) 1997: Eliseu, Gitman, IBMEC, Hess. 2001: Fontoura, Gitman, Matarazzo. 2008: Fortuna, Gitman, Matarazzo. (H) 1997: Contador. 2001: Finnerty, Contador. 2008: Contador. (L) Porter, Porter [2]. Woodwaed, Lerner, OCDE, Araújo, GEIPOT. 2001: Eliseu, Porter. 2008: Davenport, Ghemawat, Porter. (M) 1997: Ansoff, Eliseu, Hampton, Florentino. 2001: Horngren, Lambert, Mintzberg. 2008: Copeland, Gianesi, Horngren, Kotler, Eliseu, Mintzberg, Nonaka. (N) 2008: Furtado. (O) 1997: Neves, Hess, Buffa, Hollanda, Simonsen. 2001: Matus, Slack. 2008: Ballou, Mattos, Slack. (Q) 2001: Jannuzzi. 2008: Barbieri, Protocolo de Kyoto. (R) 1997: Mello. 2001: Vasconcellos, Villaça. (Z) 2001: Revista BNDES. 2008: Revista BNDES, PPP, PAC. (2) 1997: Vlack, Valmulack, Resende.

Recebido para publicação em: 07/10/2015. Aceito para publicação em: 16/12/2015. 


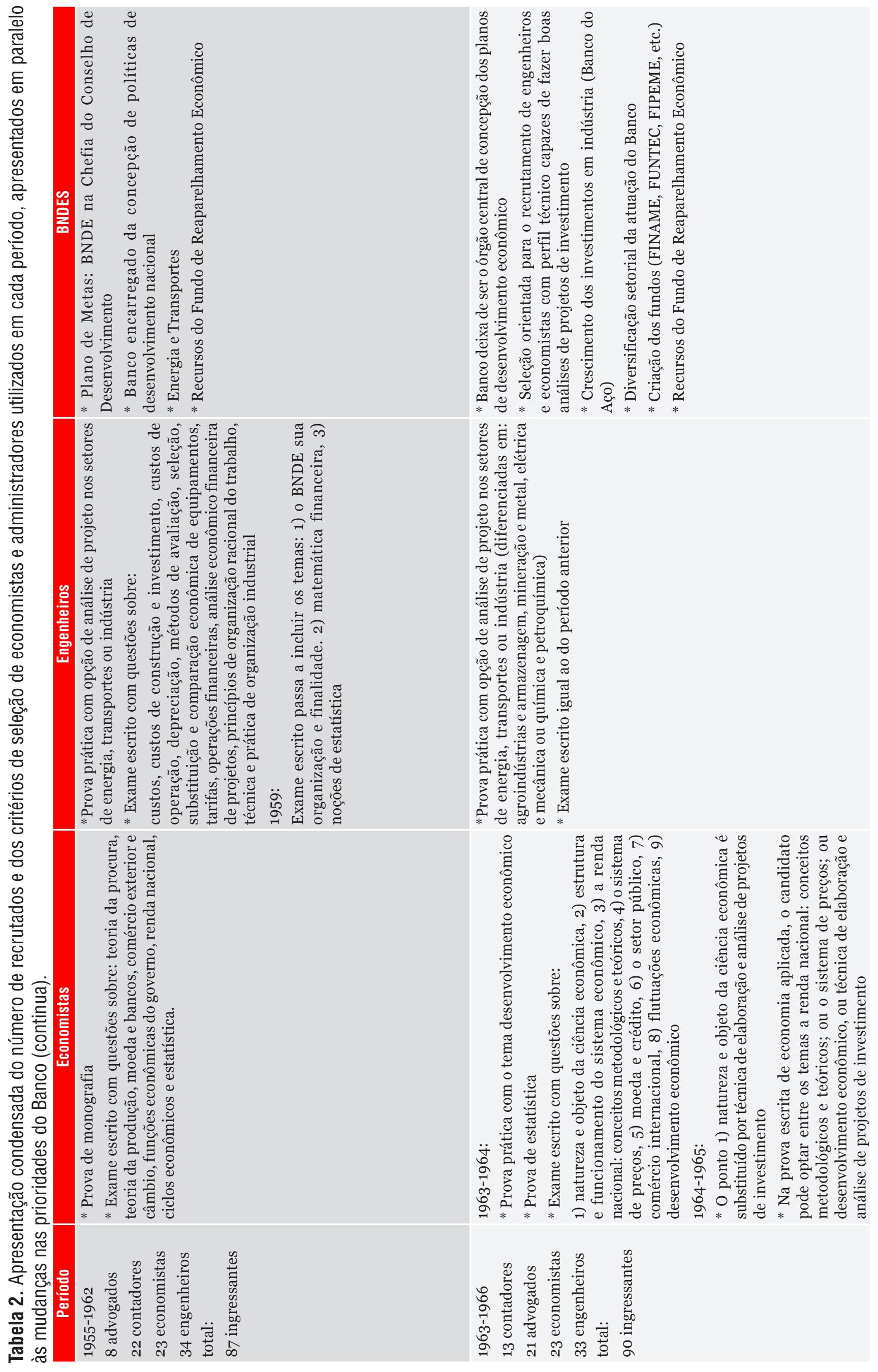




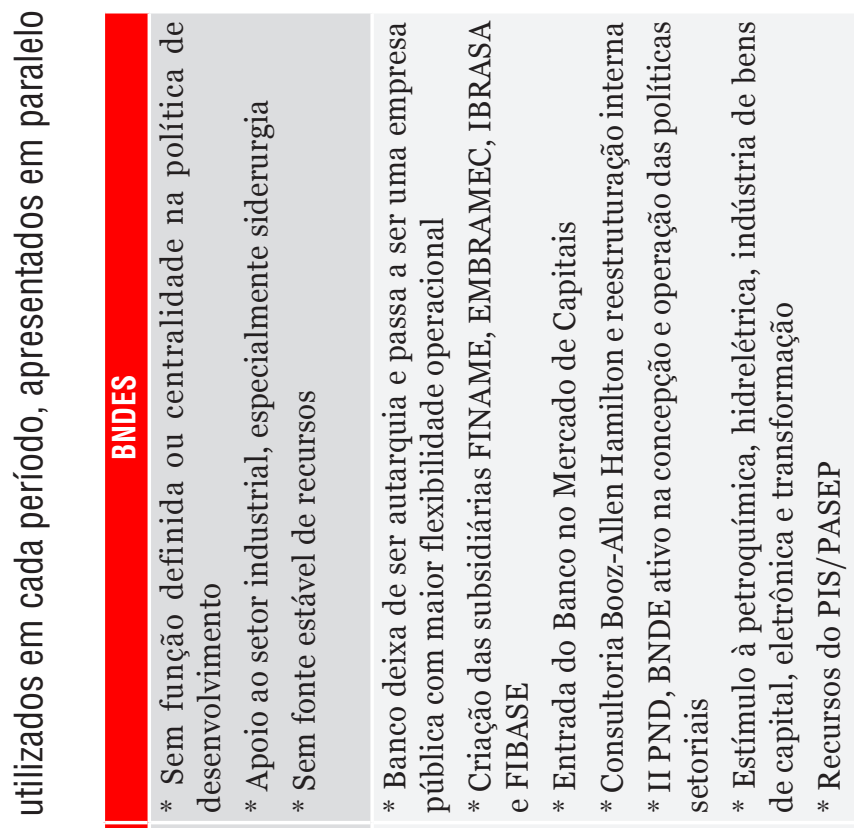

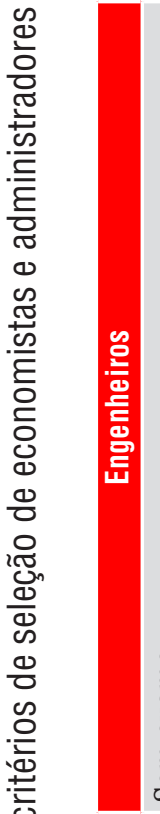
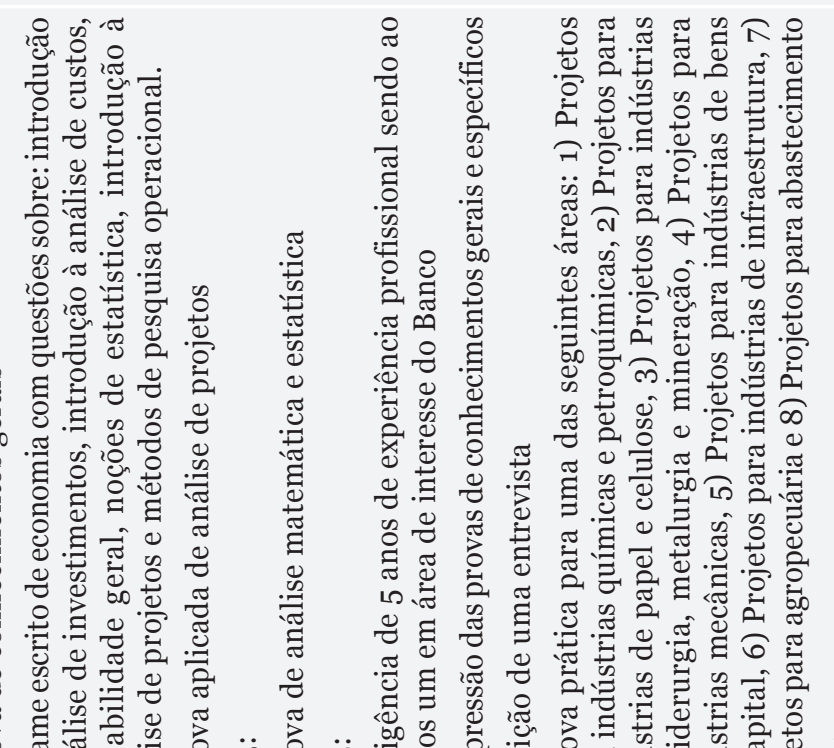

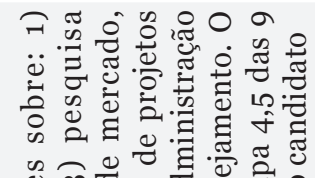

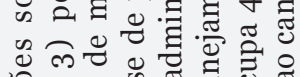
苟 혼

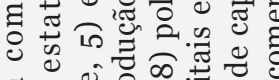
ส घี ๙

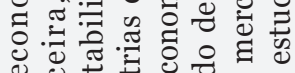
\%

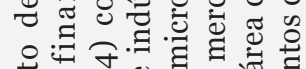
可 ฮั

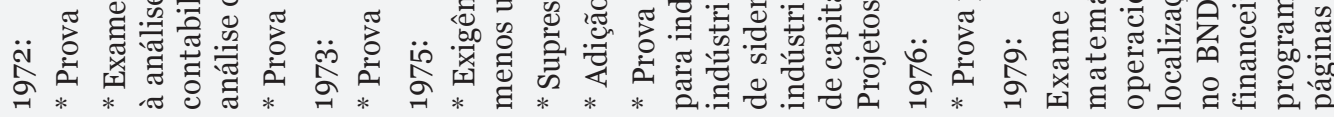

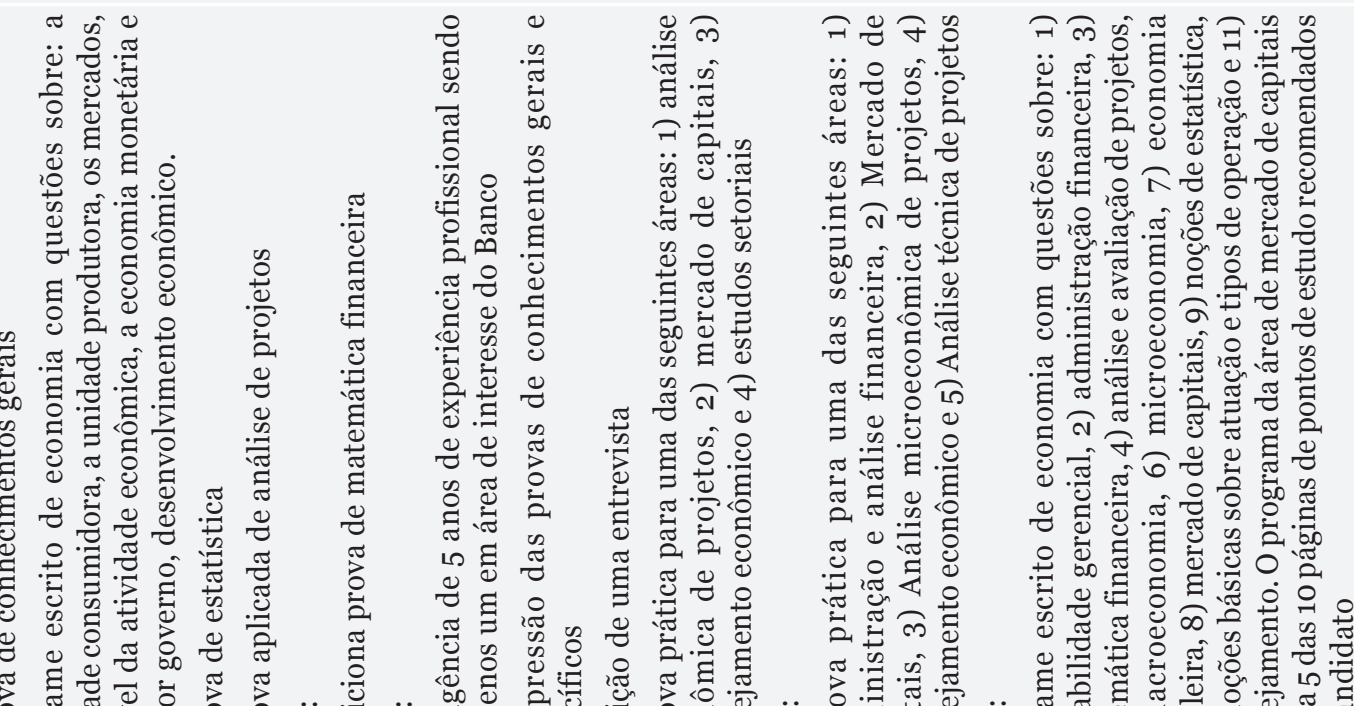

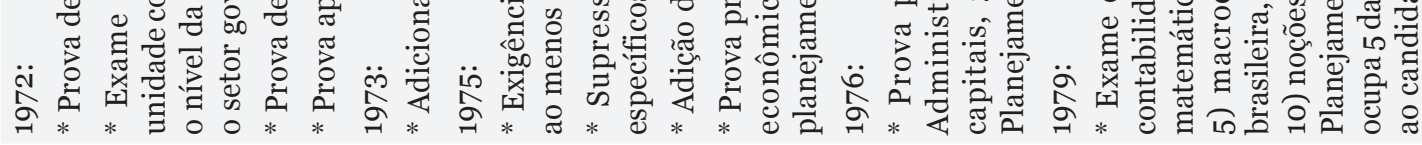
突 흔

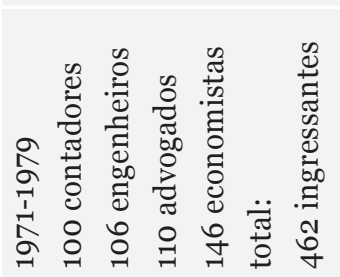




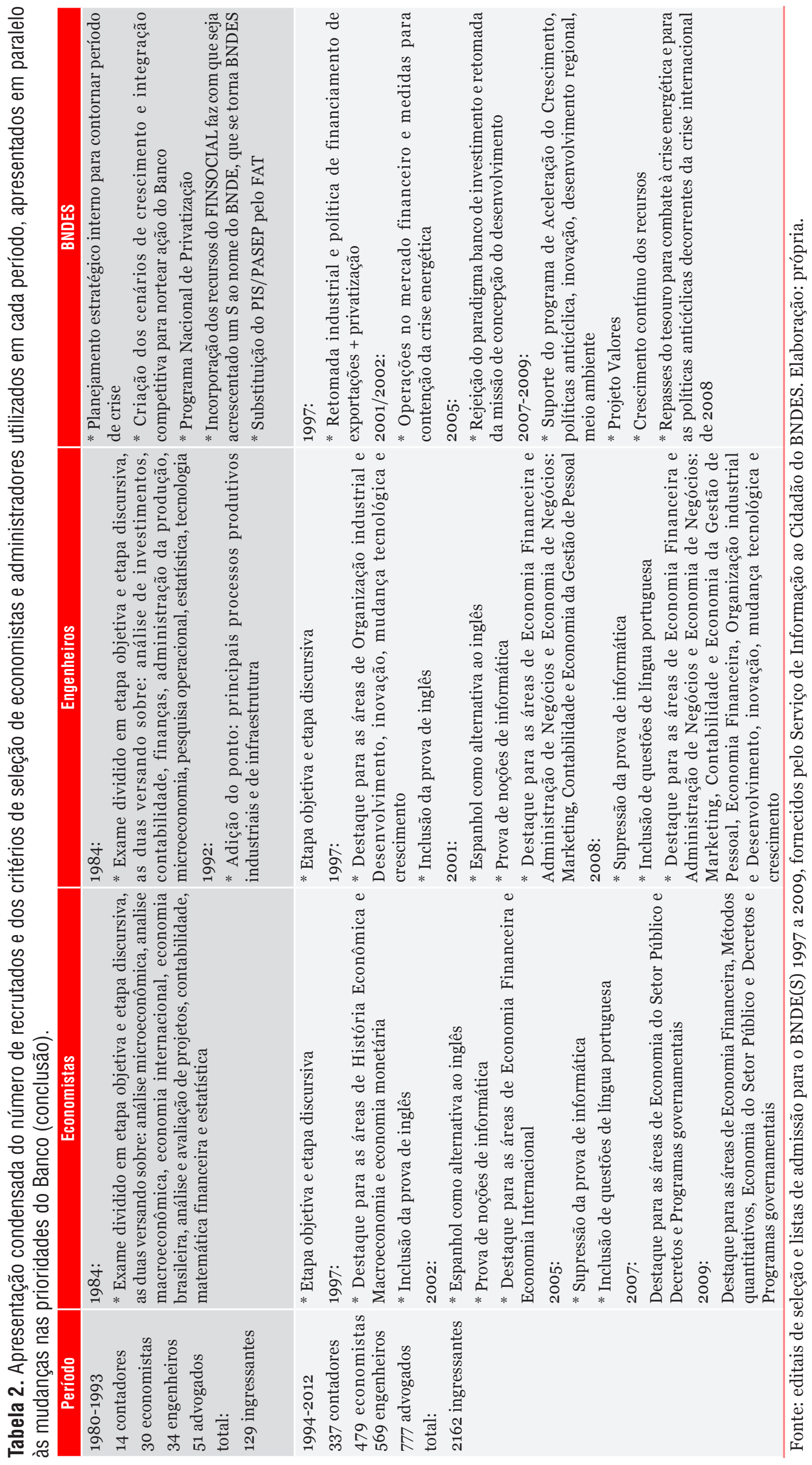

